\author{
Marquette University \\ e-Publications@Marquette
}

3-1-2017

\title{
Correlating Methane Production to Microbiota in Anaerobic Digesters Fed Synthetic Wastewater
}

Kaushik Venkiteshwaran

Marquette University, kaushik.venkiteshwaran@marquette.edu

K. Milferstedt

INRA

M. Fujimoto

Marquette University

M. Johnson

University of Kentucky

Daniel Zitomer

Marquette University, daniel.zitomer@marquette.edu

Follow this and additional works at: https://epublications.marquette.edu/civengin_fac

Part of the Civil Engineering Commons

\section{Recommended Citation}

Venkiteshwaran, Kaushik; Milferstedt, K.; Fujimoto, M.; Johnson, M.; and Zitomer, Daniel, "Correlating Methane Production to Microbiota in Anaerobic Digesters Fed Synthetic Wastewater" (2017). Civil and Environmental Engineering Faculty Research and Publications. 141.

https://epublications.marquette.edu/civengin_fac/141 


\title{
Correlating Methane Production to Microbiota in Anaerobic Digesters Fed Synthetic Wastewater
}

\author{
K. Venkiteshwaran \\ Department of Civil, Construction and Environmental \\ Engineering, Marquette University, \\ Milwaukee, WI \\ K. Milferstedt
}

LBE, INRA, 102 Avenue des Etangs, Narbonne, F-11100, France

J. Hamelin

LBE, INRA, 102 Avenue des Etangs, Narbonne, F-11100, France

M. Fujimoto

Department of Civil, Construction and Environmental

Engineering, Marquette University,

Milwaukee, WI

M. Johnson

Department of Electrical and Computer Engineering,

University of Kentucky,

Lexington, $K Y$

D. H. Zitomer

Department of Civil, Construction and Environmental

Engineering, Marquette University,

Milwaukee, WI 


\begin{abstract}
A quantitative structure activity relationship (QSAR) between relative abundance values and digester methane production rate was developed. For this, 50 triplicate anaerobic digester sets (150 total digesters) were each seeded with different methanogenic biomass samples obtained from full-scale, engineered methanogenic systems. Although all digesters were operated identically for at least 5 solids retention times (SRTs), their quasi steady-state function varied significantly, with average daily methane production rates ranging from $0.09 \pm 0.004$ to $1 \pm 0.05 \mathrm{~L}-\mathrm{CH}_{4} / \mathrm{L}_{\mathrm{R}}$-day $\left(L_{R}=\right.$ Liter of reactor volume) (average \pm standard deviation). Digester microbial community structure was analyzed using more than 4.1 million partial 16S rRNA gene sequences of Archaea and Bacteria. At the genus level, 1300 operational taxonomic units (OTUs) were observed across all digesters, whereas each digester contained $158 \pm 27$ OTUs. Digester function did not correlate with typical biomass descriptors such as volatile suspended solids (VSS) concentration, microbial richness, diversity or evenness indices. However, methane production rate did correlate notably with relative abundances of one Archaeal and nine Bacterial OTUs. These relative abundances were used as descriptors to develop a multiple linear regression (MLR) QSAR equation to predict methane production rates solely based on microbial community data. The model explained over $66 \%$ of the variance in the experimental data set based on 149 anaerobic digesters with a standard error of $0.12 \mathrm{~L}-\mathrm{CH}_{4} / \mathrm{LR}_{\mathrm{R}}$-day. This study provides a framework to relate engineered process function and microbial community composition which can be further expanded to include different feed stocks and digester operating conditions in order to develop a more robust QSAR model.
\end{abstract}

Keywords: Amplicon sequencing, Anaerobic digestion, Bioindicator, Microbial community composition, Multiple linear regression, Quantitative structure activity relationship

\title{
1. Introduction
}

There is an increasing emphasis among industries and municipalities to achieve sustainability goals by shifting from wastewater treatment to energy generation and resource recovery using anaerobic biotechnology (Angenent et al., 2004 and Novotny et al., 2010; van Loosdrecht and Brdjanovic, 2014). However, challenges still remain regarding anaerobic biotechnology implementation, as much is undetermined about the microbial factors that distinguish between a healthy and unhealthy digester (Leitão et al., 2006). Current mathematical models used for designing anaerobic treatment plants such as ADM1 (Batstone et al., 2002) typically do not include microbial diversity information and rely on the assumption that each trophic group in the anaerobic digestion (AD) process is composed of a single taxon (Ramirez et al., 2009). In 
ADM1, the seven trophic groups correspond to the degradation of sugars, amino acids, long chain fatty acids, acetate, propionate, butyrate-valerate and hydrogen. ADM1 requires the input of 24 variables, of which seven relate to microbial function associated with these seven trophic groups. One of the major reasons that microbial community parameters are not included in models is because inadequate microbiological data exist; specifically community structure-function relationships and kinetic data are missing. Therefore, in order to improve the predictability of current models, understanding regarding how the microbial community structure relate to process function, such as methane generation, must be deepened (Curtis et al., 2003).

Microbial biomass concentration, along with microbial community descriptors such as; microbial richness, diversity and evenness have been described in previous studies to correlate with anaerobic digester function and stability when operating under transient conditions such as variable influent organic strength (Hashsham et al., 2000 and Fernandez et al., 2000). However, the relationships established are qualitative, not quantitative nor predictive. A few studies using multiple linear regression (MLR) modeling have reported quantitative linear relationships between Archaeal (i.e, methanogen) descriptors and their activity ( Venkiteshwaran et al., 2015). Tale et al. (2011) applied MLR to anaerobic digester data, relating specific methanogenic activities to community structures, as defined by DGGE banding patterns targeting the methyl coenzyme A gene ( $m c r A$ ) from methanogens. The abundance of mcrA was also shown to be linearly correlated with specific methanogenic activity of four $\mathrm{H}_{2} / \mathrm{CO}_{2}$ enrichment cultures (Morris et al., 2014). Bocher et al. (2015) used the mcrA DGGE banding pattern from a large set of 49 distinct biomass samples to develop two MLR equations to predict specific methanogenic activity (SMA) against propionate and glucose, respectively. Taken together, these studies applied MLR modeling, targeting the methanogen population only (i.e, $m c r A$ ), to predict specific methanogenic activity values in batch experiments, and not at steady state in a continuous operation mode.

However, since AD involves both Archaea and Bacteria, this study investigated whether both Archaeal and Bacterial

Water Research, Vol 110 (March 2017): pg. 161-169. DOI. This article is (C Elsevier and permission has been granted for this version to appear in e-Publications@Marquette. Elsevier does not grant permission for this article to be further copied/distributed or hosted elsewhere without the express permission from Elsevier. 
microorganisms are good descriptors in an MLR model that can predict digester operation. This report describes a relationship between digester operation after a period of more than five SRTs and the relative abundance of Archaea as well as Bacteria. This is in contrast to the previous work in which a standard bioassay parameter, SMA, was related to relative abundance values of only methanogens. The SMA value is determined in a batch test and is not similar to the standard operational conditions of full-scale plants.

In this study we use high throughput sequencing of partial $16 \mathrm{~S}$ rRNA gene amplicons from both Archaeal and Bacterial populations. To include a large data set and diversity of anaerobic microorganisms, multiple digester sets (i.e, 50), each containing triplicate digester, started with different seed biomass were operated under identical conditions. Digesters were acclimated for a minimum of 5 hydraulic retention times (HRTs) before functional data and microbial community samples were collected. Subsequently, a predictive, quantitative structure activity relationship (QSAR) between anaerobic microbial community descriptors and digester methane production rate was developed.

\section{Materials and methods}

\subsection{Seed inocula}

Biomass samples were obtained from 50 full-scale, engineered methanogenic systems that were geographically diverse (from 49 states within the United States) and used to inoculate lab-scale digesters (Table S1). No anaerobic systems were found in Rhode Island, and two samples were obtained from different anaerobic systems (Systems A and B) in Wisconsin (WI). One sample was obtained from each of the remaining 48 states. Methanogenic biomass was from 25 anaerobic systems treating industrial waste (food, dairy and brewery industries) and 25 digesters stabilizing municipal wastewater sludge. One sample was from an AnMBR (TX) and six biomass samples were from upflow anaerobic sludge blanket (UASB) reactors (from Alabama ( $A L)$, Arkansas (AR), Colorado (CO), Idaho (ID), Kansas (KS) and Wisconsin A (WI A) with granular biomass; all other samples were flocculent biomass from continuous stirred-tank

Water Research, Vol 110 (March 2017): pg. 161-169. DOI. This article is @ Elsevier and permission has been granted for this version to appear in e-Publications@Marquette. Elsevier does not grant permission for this article to be further copied/distributed or hosted elsewhere without the express permission from Elsevier. 
reactors (CSTRs). With the exception of a thermophilic digester in Michigan (MI), biomass samples were from mesophilic systems.

\subsection{Laboratory digester operation}

Each biomass sample was used to inoculate a set of three laboratory digesters that were $160 \mathrm{~mL}$ serum bottles with $50 \mathrm{~mL}$ of active volume incubated at $35 \pm 2{ }^{\circ} \mathrm{C}$ on a shaker table. Inocula containing granular biomass from UASB systems were blended using a bench-top blender for $10 \mathrm{~s}$ prior to seeding the digesters to disrupt the granules. Effluent removal and feeding was done manually by inserting a needle with a plastic syringe through serum bottle septa (Tale et al., 2011, Tale et al., 2015 and Carey et al., 2016). A 10-day hydraulic retention time (HRT) was maintained by removing $5 \mathrm{~mL}$ of effluent and adding an equal volume of synthetic industrial wastewater every day (Tale et al., 2011, Tale et al., 2015 and Venkiteshwaran et al., 2016). Synthetic industrial wastewater was a mixture of non-fat dry milk (Roundy's Supermarkets, Inc., Milwaukee, WI USA) containing 52\% $\mathrm{w} / \mathrm{w}$ sugars and $35 \% \mathrm{w} / \mathrm{w}$ proteins, $10 \mathrm{~g} / \mathrm{L} \mathrm{NaHCO}_{3}$ and nutrient medium. The nutrient medium, as described by Speece (2008), contained the following [mg/l]: $\mathrm{NH}_{4} \mathrm{Cl}[400] ; \mathrm{MgSO}_{4} \cdot 6 \mathrm{H}_{2} \mathrm{O}[250] ; \mathrm{KCl}$ [400]; $\mathrm{CaCl}_{2} \cdot 2 \mathrm{H}_{2} \mathrm{O}$ [120]; $\left(\mathrm{NH}_{4}\right)_{2} \mathrm{HPO}_{4}$ [80]; $\mathrm{FeCl}_{3} \cdot 6 \mathrm{H}_{2} \mathrm{O}$ [55]; $\mathrm{CoCl}_{2} \cdot 6 \mathrm{H}_{2} \mathrm{O}[10] ; \mathrm{KI}[10]$; the salts $\mathrm{MnCl}_{2} \cdot 4 \mathrm{H}_{2} \mathrm{O}, \mathrm{NH}_{4} \mathrm{VO}_{3}, \mathrm{CuCl}_{2} \cdot 2 \mathrm{H}_{2} \mathrm{O}$, $\mathrm{Zn}\left(\mathrm{C}_{2} \mathrm{H}_{3} \mathrm{O}_{2}\right)_{2} \cdot 2 \mathrm{H}_{2} \mathrm{O}, \mathrm{AlCl}_{3} \cdot 6 \mathrm{H}_{2} \mathrm{O}, \mathrm{Na}_{2} \mathrm{MoO}_{4} \cdot 2 \mathrm{H}_{2} \mathrm{O}, \mathrm{H}_{3} \mathrm{BO}_{3}, \mathrm{NiCl}_{2} \cdot 6 \mathrm{H}_{2} \mathrm{O}$, $\mathrm{NaWO}_{4} \cdot 2 \mathrm{H}_{2} \mathrm{O}$, and $\mathrm{Na}_{2} \mathrm{SeO}_{3}$ ) [each at 0.5]; yeast extract [100]; and resazurin [1]. Resazurin was used as an indicator of dissolved oxygen in the digesters.

All digesters were seeded at an initial volatile suspended solids (VSS) concentration of $8 \mathrm{~g} / \mathrm{L}$ and operated at an organic loading rate (OLR) of $3 \mathrm{~g} \mathrm{COD/L-day} \mathrm{(COD} \mathrm{=} \mathrm{Chemical} \mathrm{oxygen} \mathrm{demand).} \mathrm{This} \mathrm{OLR}$ was identified after a preliminary investigation in which five inocula were tested at OLR values of 2, 3, 4 and $5 \mathrm{~g}$ COD/L-day. The purpose of the preliminary investigation was to identify a sustainable OLR that did not result in digester failure (i.e., digester $\mathrm{pH}<6.5$ and methane production less than $20 \%$ of theoretical maximum), but challenged the system with a high OLR to observe a wide range of COD removal and methane production rates. An OLR of $2 \mathrm{~g}$ COD/L-day resulted in $>98 \pm 0.1 \%$ COD removal for all digesters. In contrast, all preliminary

Water Research, Vol 110 (March 2017): pg. 161-169. DOI. This article is $(\subset)$ Elsevier and permission has been granted for this version to appear in e-Publications@Marquette. Elsevier does not grant permission for this article to be further copied/distributed or hosted elsewhere without the express permission from Elsevier. 
digesters failed at OLR values of 4 and $5 \mathrm{~g}$ COD/L-day. Therefore, the $3 \mathrm{~g} \mathrm{COD/L-day} \mathrm{OLR} \mathrm{was} \mathrm{used} \mathrm{for} \mathrm{subsequent} \mathrm{testing} \mathrm{since} \mathrm{it} \mathrm{did} \mathrm{not}$ cause failure, but resulted in 60-90\% COD removal for the inocula tested.

Biogas production volume was measured daily from day 0 by inserting a needle with a wetted glass barrel syringe through serum bottle septa. After 50 days of operation, the systems were assumed to be at a quasi-steady state based on less than $20 \%$ variation (standard deviation) in daily biogas production (Venkiteshwaran et al., 2016). Digester biogas and effluent samples were then collected for quasi steady state functional analysis over seven consecutive days. The functional analyses of all digesters were conducted between Day 5065 of their respective operation. Functional parameters measured included biogas methane concentration, effluent volatile fatty acids (VFAs) and soluble COD (SCOD) concentrations. In addition, volatile suspended solids (VSS) and $\mathrm{pH}$ were measured on day seven of the analysis period. Biogas methane concentration was quantified by gas chromatography (GC System 7890A, Agilent Technologies, Irving, TX, USA) using a thermal conductivity detector. SCOD was measured by filtering the sample through a $0.45 \mu \mathrm{m}$ membrane syringe filter and determining the filtrate COD by standard methods (APHA et al., 1998). VFA concentrations were measured by gas chromatography (GC System 7890A, Agilent Technologies, Irving, TX, USA) using a flame ionization detector. Digester VSS were determined by standard methods (APHA et al., 1998). The $\mathrm{pH}$ was measured using a $\mathrm{pH}$ meter (Orion 4 Star, Thermo, Waltham, MA, USA).

\subsection{Microbial community analyses}

Digester effluent samples ( $1 \mathrm{~mL}$ ) were collected for DNA extraction on six consecutive days when digester functional analyses were performed and pooled. Each day, the effluent samples were centrifuged at 10,000 RPM (9400 g) for $10 \mathrm{~min}$. Centrifuged solids for consecutive days were combined at equal proportions and DNA was extracted using a commercial kit according to manufacturer instructions (PowerSoil ${ }^{\mathrm{TM}}$ DNA Isolation Sample Kit, MoBio Laboratories, Inc., Carlsbad, CA). Biomass samples were subjected to an initial bead beating step for $10 \mathrm{~min}$ on a vortexer (Model 58,816-

Water Research, Vol 110 (March 2017): pg. 161-169. DOI. This article is $(\subset)$ Elsevier and permission has been granted for this version to appear in e-Publications@Marquette. Elsevier does not grant permission for this article to be further copied/distributed or hosted elsewhere without the express permission from Elsevier. 
121, VWR International, Radnor, PA, USA). DNA extraction from one digester inoculated with biomass from North Dakota (ND3) failed. Therefore, data from this digester were excluded from further analysis and data from the remaining 149 digesters were subsequently employed.

Forward and reverse primers 515-532U and 909-928U (Wang and Qian, 2009) were used to amplify the V4-V5 variable region of the Bacterial and Archaeal 16S rRNA genes. Previous studies have used these primer pairs for studying methanogenic communities. ( Braun et al., 2015, Resende et al., 2015 and Venkiteshwaran et al., 2016). The DNA sample and primers with their respective linkers were amplified over 30 cycles at an annealing temperature of $65^{\circ} \mathrm{C}$. An index sequence was added in a second PCR reaction of 12 cycles, and the resulting products were purified and loaded onto the Illumina MiSeq cartridge for sequencing of paired 300 bp reads following manufacturer instructions (Reagent Kit v3, Illumina, Inc., San Diego, CA USA). Sequencing work was performed at the Genotoul Lifescience Network Genome and Transcriptome Core Facility in Toulouse, France (get.genotoul.fr).

Forward and reverse sequences were assembled and quality checked using a modified version of the standard operation procedure by Kozich et al. (2013) in Mothur version 1.33.0, including chimera detection by sample using the uchime implementation in Mothur. Zero ambiguous bases and zero unknown bases $(\mathrm{N})$ were allowed.

Preclustering of sequences was done to minimize noise because of random sequencing errors. Sequences were allowed to cluster with up to four bases difference over an average length of $375 \mathrm{bp}$. Singletons and sequences found only twice were removed from the analysis. Sequence alignment and taxonomic outlining was accomplished using SILVA SSURef NR99, release 119, as provided by Schloss et al. (2009). The same database was used in Mothur's classify. seqs() command to assign taxonomic affiliation using a cutoff value of $80 \%$. Final sequence data were clustered in 1300 operational taxonomic units (OTUs) at $97 \%$ similarity and rarified to the lowest sequence reads per sample $(27,315$ reads).

Water Research, Vol 110 (March 2017): pg. 161-169. DOI. This article is (C) Elsevier and permission has been granted for this version to appear in e-Publications@Marquette. Elsevier does not grant permission for this article to be further copied/distributed or hosted elsewhere without the express permission from Elsevier. 


\subsection{Initial screening to select significant OTUs}

Initial screening was performed to select OTUs with relative abundances that were highly correlated with average methane production rates. Initial screening was done by performing 50 iterations to build 50 Spearman's rank correlation matrices. In each iteration, the Spearman's rank correlation coefficients for the relative abundance of each of the 1300 OTUs and the average methane production rates were calculated using data from 75 (of the total 149) randomly selected digesters to obtain 50 unique Spearman's matrices. Multiple, unique Spearman's matrices were desired so that OTUs that consistently showed strong correlation with methane production could be identified. The Spearman's rank matrices were checked to ensure that all 149 digesters were included at least once among the 50 iterations. Spearman's rank was employed as a measure of monotonic statistical dependence because of its robustness since it does not require underlying assumptions regarding the frequency of distribution of variables (e.g., normal distribution, uniformly distributed etc.) or the existence of a linear relationship between variables (Zuur et al., 2007).

The 10 OTUs with relative abundance values most positively related (i.e., having the highest Spearman rank scores) and the 10 OTUs most negatively related (i.e., having the lowest Spearman rank scores) to methane production rates were selected during each of the initial 50 screening iterations. The OTUs which were repeatedly selected in more than $75 \%$ of the 50 initial screening iterations were deemed to be highly significant. Relative abundance values of these highly significant OTUs were subsequently used to develop the QSAR linear regression model.

\subsection{Linear model and QSAR equation}

A MLR leave group out (LGO) approach was employed to validate a quantitative relationship between relative abundance values of the 10 highly significant OTUs identified during initial screening. Digesters were randomly partitioned into 10 subsets of 14 or 15 digesters each. Subsequently, ten validation tests were performed. In each test, 9 of these 10 subsets were combined and used as a training

Water Research, Vol 110 (March 2017): pg. 161-169. DOI. This article is (C) Elsevier and permission has been granted for this version to appear in e-Publications@Marquette. Elsevier does not grant permission for this article to be further copied/distributed or hosted elsewhere without the express permission from Elsevier. 
set to develop an MLR equation, whereas the remaining subset was used as a validation set to test the equation predictability. This was repeated until all 10 digester subsets were used once as a validation subset.

The predictability of the MLR equation was deemed good if the following four criteria were met (Golbraikh and Tropsha, 2000 and Konovalov et al., 2008): (1) $q^{2}>0.5$, (2) $R^{2}>0.6,(3)\left(R^{2}-\right.$ $\left.\mathrm{R}_{0}{ }^{2}\right) / \mathrm{R}^{2}<0.1$ and (4) $0.85 \leq K \leq 1.15$. For this, $\mathrm{q}^{2}$ is the chi square value calculated using the observed versus predicted methane production values described by Schüürmann et al. (2008) and $R^{2}$ is the coefficient of determination for the linear regressions of predicted versus observed methane production rates. Additionally, $\mathrm{R}_{\mathrm{O}}{ }^{2}$ and $\mathrm{K}$ are the coefficient of determination and the slope for the test set linear regression equation of predicted versus observed methane production rates forced through the origin, respectively.

After confirming that MLR equations demonstrated good predictability, all 10 digester subsets were combined and used to determine a final, QSAR linear regression model.

\subsection{Analytical methods}

Average, standard deviation, variance and $t$-test calculations were performed using Excel 2010 (Version 14.3.2 - Microsoft, USA) built in functions. Richness $(S)$, Shannon diversity $(H)$, and evenness $(E)$ indices were calculated from the abundance tables. Richness was calculated as the number of OTUs identified at the genus level. The Shannon-Weaver diversity index values were determined as described by Briones et al. (2007). Evenness was calculated as described by Falk et al. (2009). Principal Coordinates analysis (PCoA) was performed using the R software environment (R Core Team, 2015). ANOSIM using Bray-Curtis dissimilarity was performed to assess the relationship between methane production and relative abundance values microbial community using the vegan package in $\mathrm{R}$ (Oksanen et al., 2016). The Bray-Curtis dissimilarity, Spearman rank correlation and MLR analyses were performed using Excel 2010 (Version 14.3.2 Microsoft, USA) with the added statistical software package XLStat Pro 2014 (Addinsoft, USA). Blast search of representative sequences was conducted using default settings and excluding uncultured sequences

Water Research, Vol 110 (March 2017): pg. 161-169. DOI. This article is @ Elsevier and permission has been granted for this version to appear in e-Publications@Marquette. Elsevier does not grant permission for this article to be further copied/distributed or hosted elsewhere without the express permission from Elsevier. 
on the browser based blastn tool (https://blast.ncbi.nlm.nih.gov/) (Altschul et al., 1990).

\section{Results and discussion}

\subsection{Digester function}

All digester sets were operated identically, but were seeded with different biomass. The seed biomass origin ostensibly had a significant influence on functional performance, both initially as well as after 80 days. Significant variability was observed in methane production rates $\left(0.09 \pm 0.004\right.$ to $0.98 \pm 0.05 \mathrm{~L} \mathrm{CH}_{4} / \mathrm{L}_{R}$-day) (Table S2) as well as effluent SCOD concentration ( $2.6 \pm 0.30$ to $25 \pm 1.1 \mathrm{~g} / \mathrm{L}$ ), total VFA concentration ( $1.6 \pm 3.8$ to $19 \pm 1.3 \mathrm{~g} / \mathrm{L}$ as acetic acid) and pH (5.87.6) (Fig. 1). VFAs constituted $56 \pm 12 \%$ of the effluent SCOD. 
NOT THE PUBLISHED VERSION; this is the author's final, peer-reviewed manuscript. The published version may be accessed by following the link in the citation at the bottom of the page.
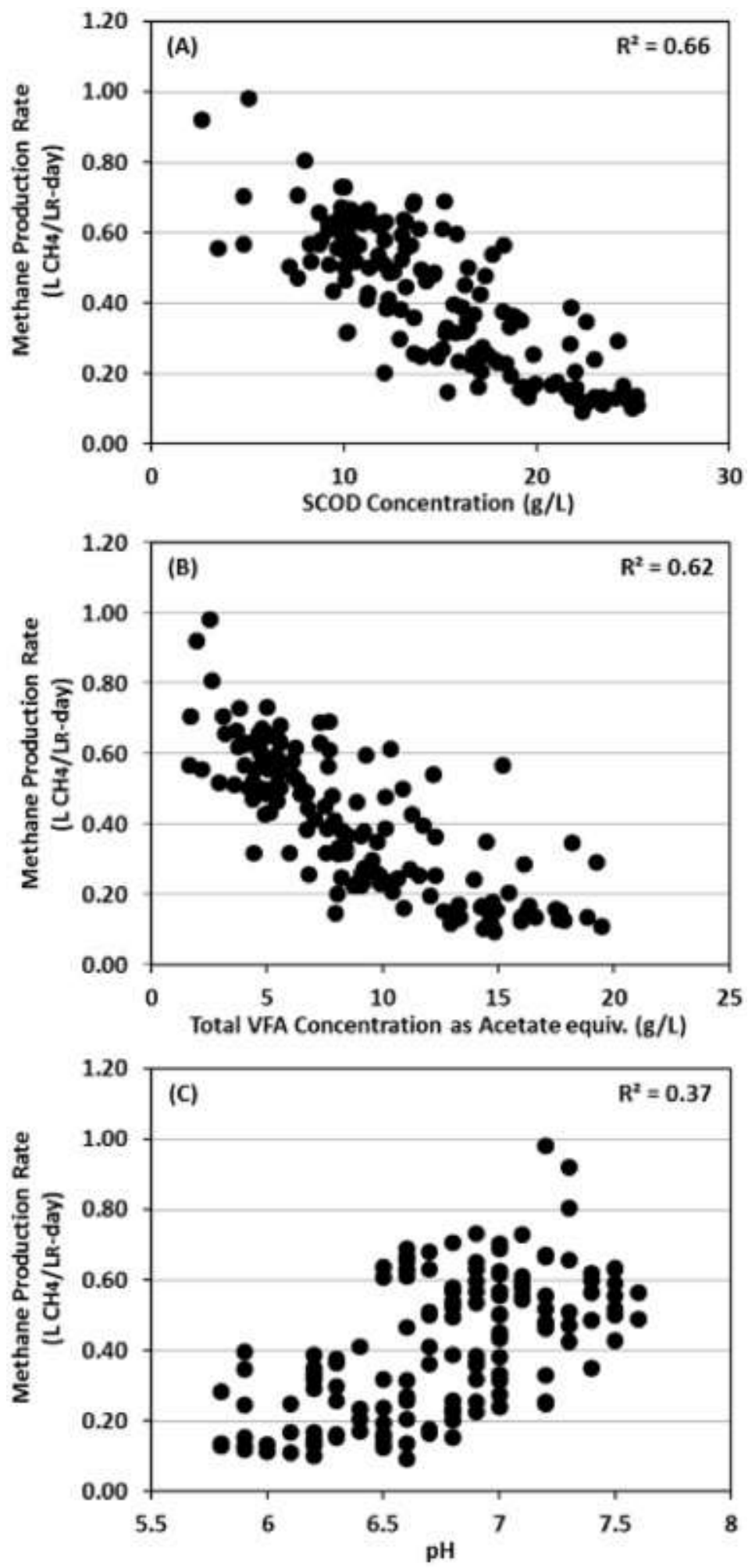

Fig. 1. Average daily methane production versus effluent parameters. Average daily methane production (L-CH4/LR-day) versus (A) SCOD concentration $(\mathrm{g} / \mathrm{L}),(\mathrm{B})$ total VFA concentration as acetic acid $(\mathrm{g} / \mathrm{L})$ and $(\mathrm{C}) \mathrm{pH}$.

Water Research, Vol 110 (March 2017): pg. 161-169. DOI. This article is @ Elsevier and permission has been granted for this version to appear in e-Publications@Marquette. Elsevier does not grant permission for this article to be further copied/distributed or hosted elsewhere without the express permission from Elsevier. 
Relationships between the methane production rates and effluent parameters were as expected: methane production was inversely correlated to effluent SCOD concentrations, effluent total VFA concentrations and $\mathrm{pH}$ (Fig. 1). Acetic acid and propionic acid contributed $55 \pm 18 \%$ and $40 \pm 20 \%$, respectively, of the total VFA equivalents (Fig. S1). Among all VFAs, the acetic acid concentrations showed the strongest linear correlation with methane production rates (Fig. S1A).

\subsection{Microbial diversity analysis}

Illumina sequencing yielded a total of 14.5 million raw sequence reads after making contigs, with 90,324 \pm 32,901 raw reads per digester sample. After filtering, quality control and chimera removal using the procedure described in section 2.3, 10 million total sequence reads with $62,943 \pm 24,560$ reads per sample were obtained. A sequence-based rarefaction analysis was performed to test for efficient OTU coverage, as shown in Fig. S2. After 27,315 sequence reads (lowest sequence reads per sample), the number of OTUs was saturated, as revealed by the asymptotic nature of the 149 rarefaction curves. Therefore, a total of 4.1 million sequence reads from all 149 digesters were analyzed with 27,315 rarified sequence reads per sample. Based on $97 \%$ similarity, 1300 microbial OTUs were observed with an average of $158 \pm 27$ observed OTUs per digester. The microbial communities of replicate (seeded from the same source) and non-replicate (seeded from different sources) digesters were compared using Bray-Curtis dissimilarity analyses. The average Bray-Curtis dissimilarity value of all replicate digester pairs $(0.19 \pm 0.1, \mathrm{n}=148)$ was significantly smaller than that for non-replicate digester pairs (0.52 $\pm 0.15, \mathrm{n}=10,878)$. Therefore, replicate digester microbial communities were more similar than communities of digesters seeded with biomass from different sources.

\subsubsection{Archaeal community}

The relative abundance of Archaeal sequences ranged from $<0.01 \%$ to $3 \%$. Fig. S3 shows Archaeal community profile at the class level across 149 digesters. Two Archaeal class Methanobacteria and Methanomicrobia were highly prevalent and were observed in $98 \%$ and

Water Research, Vol 110 (March 2017): pg. 161-169. DOI. This article is @ Elsevier and permission has been granted for this version to appear in e-Publications@Marquette. Elsevier does not grant permission for this article to be further copied/distributed or hosted elsewhere without the express permission from Elsevier. 
$89 \%$ of the digesters. Methanobacteria and Methanomicrobia were also the most dominant among the Archaeal classes, with an average relative abundance of $50 \pm 39 \%$ and $38 \pm 18 \%$ across all digesters. At genus level, methanogens of the genera Methanosarcina and Methanobacterium showed the highest average relative abundance. These two methanogens were detected in $67 \%$ and $81 \%$ of the digesters, respectively, and their combined relative abundance was $80 \pm 19 \%$ of the total Archaeal OTUs observed. Methanosarcina can perform both aceticlastic (acetate utilizing) and hydrogenotrophic (hydrogen utilizing) methanogenesis whereas; members of genus Methanobacterium are only known to perform hydrogenotrophic methanogenesis ( Liu and Whitman, 2008).

Methanosarcina have a higher growth rate and lower affinity for acetate than the only other known aceticlastic methanogen (Methanosaeta). They typically outcompete Methanosaeta in digesters with high acetate concentration ( $>500 \mathrm{mg} / \mathrm{L}$ ) ( Hori et al., 2006, Westermann et al., 1989 and Conklin et al., 2006). Since 99\% of the digesters in this study had an acetic acid concentration of more than $500 \mathrm{mg} / \mathrm{L}$, the presence of Methanosarcina as the dominant aceticlastic methanogen is reasonable.

Hydrogenotrophic methanogens including Methanobacterium are typically more tolerant than aceticlastic methanogensto stress conditions such as low $\mathrm{pH}$ and high VFA concentrations ( Liu and Whitman, 2008). The relative abundance of Methanobacterium was higher than that of Methanosarcina in 66\% of the digesters ( Fig. S4), with the average $\mathrm{pH}$ and VFA concentration of these digesters being $6.4 \pm 0.3$ and $10.1 \pm 4.5 \mathrm{~g} / \mathrm{L}$, respectively. Therefore, in these digesters, the typically higher relative abundance of Methanobacterium was probably due to the inhibition of Methanosarcina by low $\mathrm{pH}$ and high VFA concentration.

\subsubsection{Bacterial community}

Bacterial communities were dominated by the phyla Bacteroidetes, Firmicutes and Synergistes, contributing $59 \pm 17 \%$, $22 \pm 17 \%$ and $9 \pm 5 \%$ of the total Bacterial sequences, respectively. More than $99 \%$ of these three phyla were dominated by members of the class Bacteroidia, Clostridia and Synergistia, respectively, and their

Water Research, Vol 110 (March 2017): pg. 161-169. DOI. This article is (C Elsevier and permission has been granted for this version to appear in e-Publications@Marquette. Elsevier does not grant permission for this article to be further copied/distributed or hosted elsewhere without the express permission from Elsevier. 
presence were observed across all 149 digesters ( Fig. S5). It was shown previously that Proteobacteria, Firmicutes, Bacteroidetes and Chloroflexi were the four major phyla in the Bacterial domain in a survey of 21 full-scale anaerobic digesters ( Sundberg et al., 2013). The combined relative abundance of the three major Bacterial phyla found in this study was $91 \pm 8 \%$ of the total Bacterial sequences. Members of the phyla Bacteroidetes and Firmicutes are functionally diverse. These phyla contain hydrolytic bacteria as well as acidogenic, fermentative bacteria ( Noike et al., 1985, Mata-Alvarez et al., 2000, Vidal, 2000, Ariunbaatar et al., 2014 and Stiles and Holzapfel, 1997). However, metagenomic analyses have shown that a majority of species involved in anaerobic digestion still remain unclassified ( Rivière et al., 2009 and Treu et al., 2016).

The most abundant genera of the phylum Bacteroidetes observed across digesters were Bacteroides, Petrimonas, Paludibacter, Porphyromonas, VadinBC27 wastewater sludge group, unclassified M2PB4-65 termite group and unclassified Prevotellaceae (present in $>95 \%$ digesters; combined abundance $=87 \pm 12 \%$ of total Bacteroidetes). Similarly for Firmicutes, unclassified Family XI, Family $X I I I$ and Ruminococcaceae were detected in $>95 \%$ of the digesters, contributing $40 \pm 17 \%$ of the total Firmicutes sequences. Synergistes were dominated by the genus Aminobacterium. The synthetic wastewater carbon source was non-fat dry milk that contained $16 \%$ proteins by mass. Species of the genera Aminobacterium such as; Aminobacterium colombiense, Aminobacterium mobile and Aminobacterium thunnarium have been identified as amino acid fermenting bacterium ( Baena et al., 1998, Baena et al., 2000 and Hamdi et al., 2015). Therefore, detection of genus Aminobacterium in systems fed with protein is reasonable.

Microbial biomass concentration (measured as VSS concentration), microbial richness, Shannon-Weaver diversity and evenness indices did not correlate with digester methane production rates (Fig. 2). Although it is generally assumed that digesters with higher biomass VSS concentration achieve higher biogas production rates compared to similar digesters with lower biomass concentration, results indicate that having a higher VSS concentration cannot be universally considered to yield better function.

Water Research, Vol 110 (March 2017): pg. 161-169. DOI. This article is (C) Elsevier and permission has been granted for this version to appear in e-Publications@Marquette. Elsevier does not grant permission for this article to be further copied/distributed or hosted elsewhere without the express permission from Elsevier. 
NOT THE PUBLISHED VERSION; this is the author's final, peer-reviewed manuscript. The published version may be accessed by following the link in the citation at the bottom of the page.
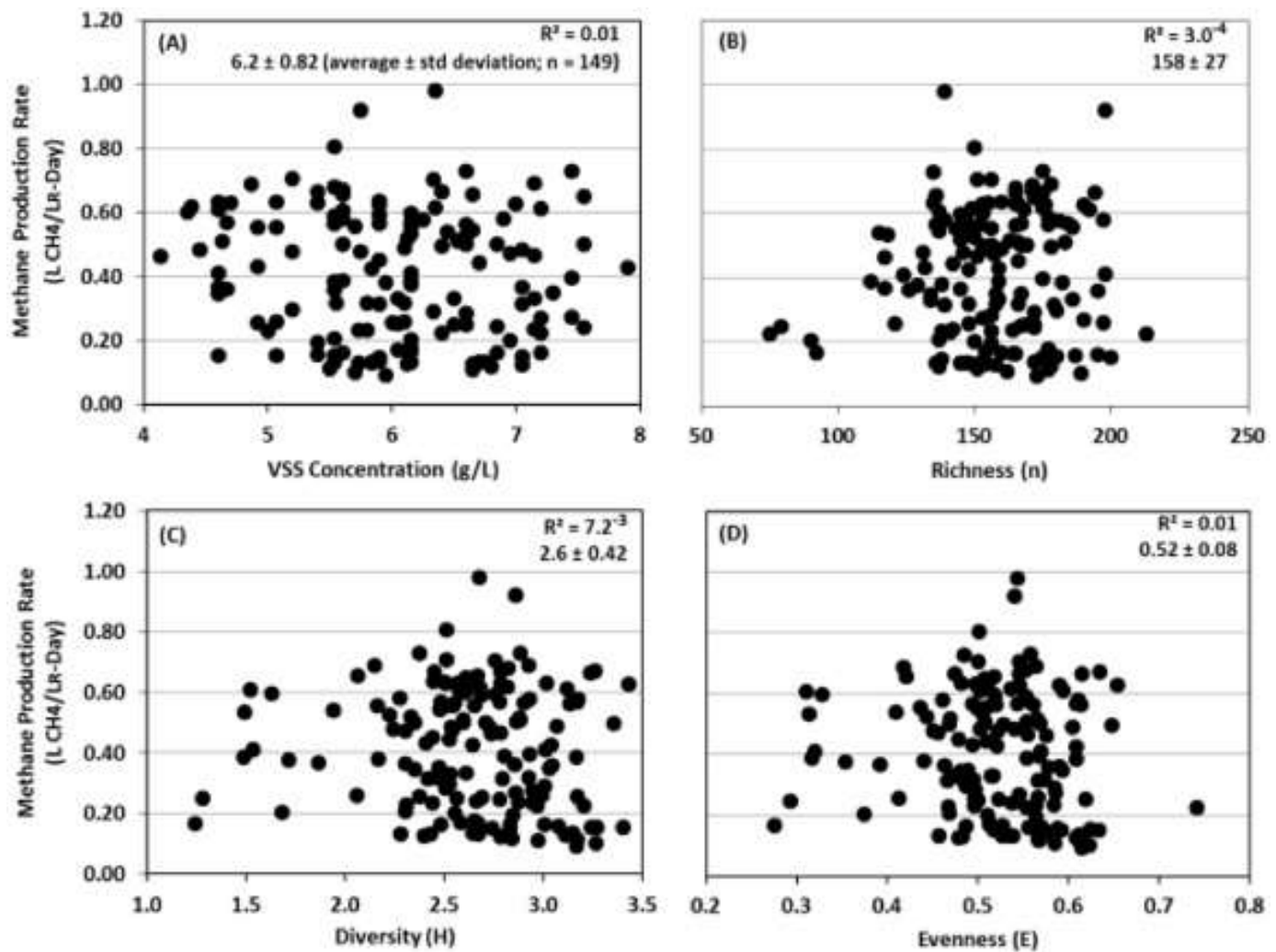

Fig. 2. Average methane production (L-CH4/LR-day) versus (A) VSS Concentration (B) Richness (C) Diversity (D) Evenness.

Others have reported that microbial community descriptors such as diversity and evenness indices relate to anaerobic digester function (Fernandez et al., 2000, Hashsham et al., 2000, Carballa et al., 2011 and Werner et al., 2011). Increased microbial diversity and evenness relate to increased functional resistance and resilience when conditions are not steady and influent characteristics such as flow rate, organic strength, feedstock composition and temperature vary and cause perturbations. Higher diversity results in a higher probability of functional redundancy and, thus, functional stability during and after perturbation (Fernandez et al., 2000, Hashsham et al., 2000, Carballa et al., 2011 and Werner et al., 2011).

\subsection{Initial screening and quantitative structure activity relationship (QSAR)}

Although methane production did not correlate with overall biomass concentration, richness, microbial diversity or evenness, it did

Water Research, Vol 110 (March 2017): pg. 161-169. DOI. This article is $(\subset)$ Elsevier and permission has been granted for this version to appear in e-Publications@Marquette. Elsevier does not grant permission for this article to be further copied/distributed or hosted elsewhere without the express permission from Elsevier. 
correlate with the relative abundance values of 10 OTUs identified during initial screening (Table S3).

Digesters were grouped in three roughly equally sized classes according to their methane production rate ("High", "Medium" and "Low") (Table S2). Triplicate digesters were not always grouped together in this partitioning. The methane production rates in the three categories were $0.63 \pm 0.09(n=50), 0.41 \pm 0.08(n=50)$ and $0.18 \pm 0.05(n=49)$ L- $\mathrm{CH}_{4} /$ LR-day, respectively. Microbial communities in high methane production digesters were different from those associated with medium (ANOSIM, $\mathrm{p}=0.002, \mathrm{R}^{2}=0.072$ ) and low (ANOSIM, $\mathrm{p}=0.001, \mathrm{R}^{2}=0.368$ ) methane production rates (Fig. S6A). Reducing the number of OTUs from 1300 to the 10 highly significant OTUs resulted in greater observable differences among microbial communities, increasing the observed community variation by PCoA axis-1 from 21.4 to $42.3 \%$ (Fig. S6). In addition, using only the 10 highly significant OTUs resulted in greater observable variation between high and medium (ANOSIM, $\mathrm{p}=0.001, \mathrm{R}^{2}=0.138$ ) as well as high and low (ANOSIM, $\mathrm{p}=0.001, \mathrm{R}^{2}=0.493$ ) digester groups (Fig. S6B).

Collinearity between pairs of the 10 highly significant relative abundance values was tested, since in MLR analysis, intercorrelation between any two (collinearity) or many variables (polycollinearity) can produce false models (Nirmalakhandan and Speece, 1988). Intercorrelation $\mathrm{R}^{2}$ values were relatively low, averaging $0.07 \pm 0.07$ $(n=45)$ and ranging from 0.001 to 0.34 . Therefore, collinearity problems did not exist among the 10 highly significant OTU relative abundance values (Table S4), allowing these OTUs to be used as descriptor variables for subsequent MLR analysis.

\subsubsection{Linear model validation and QSAR equation}

Ten MLR validation tests using the 10 highly significant OTUs were conducted by randomly dividing the 149 digesters into 10 groups (Table S5, Fig. S7). All four criteria for good predictability were satisfied in nine of the 10 validation iterations, indicating that the MLR approach resulted in equations with good predictability (Table S6). Therefore, the final QSAR MLR equation was generated by combining data from all 149 digesters:

Water Research, Vol 110 (March 2017): pg. 161-169. DOI. This article is (C Elsevier and permission has been granted for this version to appear in e-Publications@Marquette. Elsevier does not grant permission for this article to be further copied/distributed or hosted elsewhere without the express permission from Elsevier. 
NOT THE PUBLISHED VERSION; this is the author's final, peer-reviewed manuscript. The published version may be accessed by following the link in the citation at the bottom of the page.

equation(1)

$\mathrm{MPR}=0.4+{ }^{2-04} \cdot$ OTU1 $+1.3^{-01 * \text { OTU2 }}+2.6^{-01 * \text { OTU3 }}+6.0^{-03 *}$ OTU 4 $+4.5^{-}$

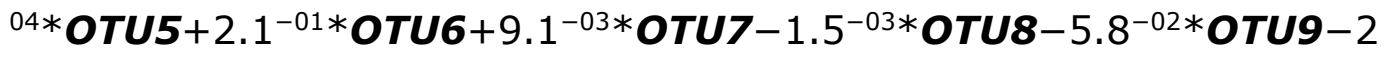
$.5^{-01}$ OTU10

$\mathbf{n}=149 ; \mathrm{R}^{2}=0.66 ; \mathrm{SE}=0.12\left(\mathrm{~L}-\mathrm{CH}_{4} / \mathrm{L}_{\mathrm{R}}-\right.$ day $)$

where MPR is the methane production rate ( $\mathrm{L}-\mathrm{CH}_{4} / \mathrm{L}_{\mathrm{R}}$-day) and OTUn is the relative abundance for taxon $n(\%)$. A plot of observed methane production rates versus rates predicted using Equation (1) for all 149 digesters is shown in Fig. 3.

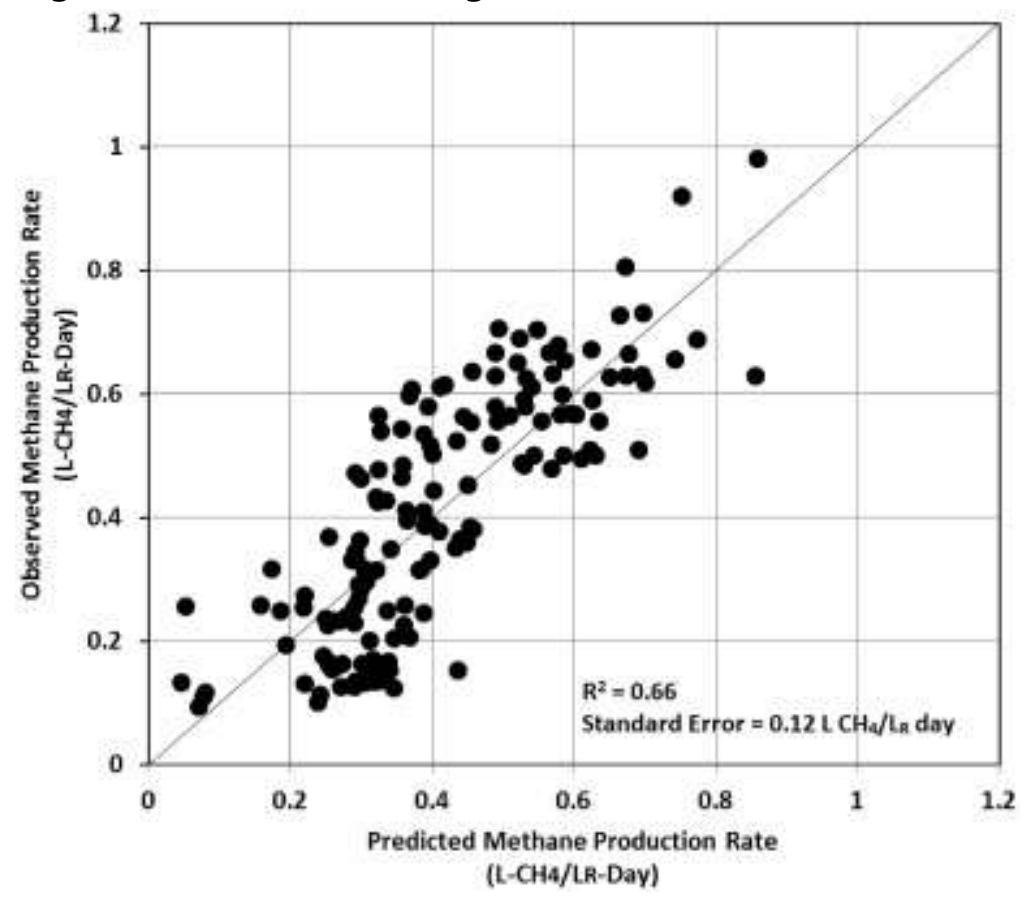

Fig. 3. Observed versus predicted methane production rate. The predicted rate was calculated using equation. ${ }^{1}$

The prevalence and range of relative abundance values for the 10 highly significant OTUs varied across all the digesters. The OTUs were prevalent in 52\% (OTU7) to 100\% (OTU1) of the 149 digesters, whereas the average relative abundance across all the digesters ranged from $0.2 \%$ (OTU6) to $8.9 \%$ (OTU8) (Table 1 ). 
Table 1. Highly significant OTUs.

\begin{tabular}{|c|c|c|c|c|c|}
\hline OTU & Order & $\begin{array}{c}\text { aPrevalence } \\
\text { (\%) }\end{array}$ & $\begin{array}{c}\text { Relative } \\
\text { abundance } \\
\text { range \& } \\
\text { (average) } \\
(\%)\end{array}$ & $\begin{array}{c}\text { Eq. (1) } \\
\text { coefficient }\end{array}$ & $\begin{array}{c}\text { Average } \\
\text { contribution value } \\
\text { (Absolute value } \\
\text { (coefficient average } \\
\text { relative } \\
\text { abundance)) })^{\mathrm{a}} 100\end{array}$ \\
\hline 1 & Bacteroidales & 100 & $\begin{array}{l}<0.01 \text { to } 36 \\
(6.5)\end{array}$ & $2^{-04}$ & 0.13 \\
\hline 2 & Bacteroidales & 77 & $\begin{array}{l}<0.01 \text { to } 1.3 \\
(0.09)\end{array}$ & $1.3^{-01}$ & 1.1 \\
\hline 3 & Spirochaetales & 67 & $\begin{array}{l}<0.01 \text { to } 0.7 \\
(0.05)\end{array}$ & $2.6^{-01}$ & 1.3 \\
\hline 4 & Bacteroidales & 98 & $\begin{array}{l}<0.01 \text { to } 54 \\
(6.1)\end{array}$ & $6^{-03}$ & 3.7 \\
\hline 5 & Clostridiales & 97 & $\begin{array}{l}<0.01 \text { to } 3.7 \\
(0.3)\end{array}$ & $4.5^{-04}$ & 0.013 \\
\hline 6 & Methanosarcinales & 54 & $\begin{array}{l}<0.01 \text { to } 2.6 \\
(0.2)\end{array}$ & $2.1^{-01}$ & 4.2 \\
\hline 7 & Clostridiales & 52 & $\begin{array}{l}<0.01 \text { to } 5.2 \\
(0.08)\end{array}$ & $9.1^{-03}$ & 0.072 \\
\hline 8 & Bacteroidales & 99 & $\begin{array}{l}<0.01 \text { to } 58 \\
(8.9)\end{array}$ & $-1.5^{-03}$ & 1.4 \\
\hline 9 & Clostridiales & 97 & $\begin{array}{l}<0.01 \text { to } 4.4 \\
(0.36)\end{array}$ & $-5.8^{-02}$ & 2.1 \\
\hline 10 & Clostridiales & 78 & $\begin{array}{l}<0.01 \text { to } 1.0 \\
(0.08)\end{array}$ & $-2.5^{-01}$ & 2.0 \\
\hline
\end{tabular}

aPrevalence $=(n / 149) \times 100 ;$ where $n=$ number of the digesters in which an OTU was observed at $>0.01 \%$ relative abundance.

The coefficients of the MLR equation (e.g., coefficient value $2^{-04}$ for OTU1) could not be used directly as indicators of the relative contribution of independent variables since the OTU average relative abundance values were different. Therefore, an average contribution value was calculated for each OTU as the absolute value of the product of the MLR coefficient and the corresponding average relative abundance (Table 1). Based on average contribution values, OTU6 was the independent variable that most significantly contributed to the predicted methane production rate, followed by OTU4 and OTU9. A blast search was conducted using the reference sequences of the 10 highly significant OTUs (Table 2). OTUs 6, 4 and 9 were most similar to Methanosarcina, unclassified Bacteroidales and unclassified Intestinimonas $s p$., respectively. Therefore, high relative abundance values of Methanosarcina and the detected unclassified Bacteroidales are ostensibly beneficial when high methane production rate is desired under the conditions studied. Similarly, low relative abundance of the detected unclassified Intestinimonas $s p$. is ostensibly beneficial. In this way, QSAR models can be employed as research tools to identify 
potentially desirable and undesirable taxa for further consideration. For example, bioaugmenting low methane producing digesters with specific taxa identified as beneficial by QSAR modeling may be promising, but more research is warranted to explore this approach.

Table 2. BLAST search results for highly significant OTUs.

\begin{tabular}{|c|c|c|c|c|c|c|}
\hline OTU & Accession \# & Name & $\begin{array}{c}\text { Query } \\
\text { length } \\
\text { (bp) }\end{array}$ & $\begin{array}{c}\text { Query } \\
\text { cover }(\%)\end{array}$ & $\begin{array}{l}\text { Identity } \\
(\%)\end{array}$ & $\begin{array}{c}E \\
\text { value }\end{array}$ \\
\hline 1 & LT558828 & $\begin{array}{l}\text { Petrimonas sulfuriphila strain } \\
\text { Marseille-P1901 }\end{array}$ & 372 & 100 & 97 & $3^{-174}$ \\
\hline 2 & KF282390 & $\begin{array}{l}\text { Cytophagaceae bacterium } \\
\text { GUDS1294 }\end{array}$ & 371 & 100 & 89 & $8^{-134}$ \\
\hline 3 & GU196244.1 & $\begin{array}{l}\text { Bacterium enrichment culture } \\
\text { clone } R 4-82 B\end{array}$ & 376 & 100 & 100 & 0.0 \\
\hline 4 & LC049960 & Bacteroidales bacterium TBC1 & 372 & 100 & 86 & $6^{-112}$ \\
\hline 5 & NR122058 & $\begin{array}{l}\text { Syntrophomonas wolfei strain } \\
\text { Goettingen G311 }\end{array}$ & 376 & 100 & 97 & $9^{-180}$ \\
\hline 6 & СР008746 & Methanosarcina barkeri CM1 & 380 & 100 & 99 & 0.0 \\
\hline 7 & NR041236 & Lutispora thermophila & 376 & 100 & 95 & $1^{-170}$ \\
\hline 8 & FJ848568 & $\begin{array}{l}\text { Porphyromonas sp. } 219216 S \\
\text { ribosomal RNA gene }\end{array}$ & 372 & 99 & 93 & $3^{-150}$ \\
\hline 9 & KP114242 & Intestinimonas sp. FSAA-17 & 375 & 100 & 99 & 0.0 \\
\hline 10 & AB910747 & Clostridium scindens & 375 & 100 & 100 & 0.0 \\
\hline
\end{tabular}

Apart from a methanogen (Methanosarcina) and a syntrophic acetogen (Syntrophomonas), the 10 descriptors also include fermenters (acidogens) ( Table 2). Also, the fermenters were both positively and negatively correlated with digester methane production rate. Of the fermenters identified at the genus level, members of Petrimonas and Porphyromonas are known to ferment sugars whereas Lutispora are amino acid fermenters ( Grabowski et al., 2005, Shah and Collins, 1988 and Shiratori et al., 2008). The positive correlation of higher methane production with high relative abundance of OTU7 (most similar to Lutispora) is reasonable since the synthetic wastewater contained protein.

Digesters exhibiting high methane production also had higher $\mathrm{pH}$ values (Fig. 1). Also, it is possible that different digester $\mathrm{pH}$ values selected for different fermenters. Studies have reported fluctuation in anaerobic digester Bacterial populations in response to variations in environmental parameters, including pH ( Lü et al., 2009 and Ogbonna et al., 2015). Digesters with near-neutral pH may have supported higher growth rates of Petrimonas and Lutispora that exhibited relative 
abundances positively correlated with methane production ( Table 2). Representative species of these genera (i.e., Petrimonas sulfuriphila and Lutispora thermophile) show optimal growth rates at neutral $\mathrm{pH}$ ( Grabowski et al., 2005 and Shiratori et al., 2008). Relative abundance of Ruminococcaceae, which was negatively correlated with methane production, has been observed to increase in digesters undergoing perturbation and with low pH ( Tian et al., 2014).

The relationship observed in this study may be based on correlation rather than causation. Additional research should be performed to determine if the microbial community composition as described by relative abundance causes digester methane production to vary. Given the many factors influencing microbial community, including wastewater composition, digester operation, environmental parameters ( $\mathrm{pH}$, temperature, salt, VFA concentration etc.) and optimal growth range of various Archaea and Bacteria (Chen et al., 2008, Enright et al., 2009 and Karakashev et al., 2005), developing a more general, robust QSAR may require extensive research using a large number of environmental conditions. This would be a worthwhile endeavor to help improve modeling and functional performance of anaerobic digesters and other engineered bioprocesses.

\section{Conclusions}

The study investigated whether microbial community descriptors can be used in a QSAR model to predict digester methane production rate. To include a large data set and diversity of anaerobic microorganisms, 50 distinct biomass samples were used to seed triplicate lab-scale digesters. Although all digesters were operated identically for a minimum of 5 retention cycles, their quasi steadystate function varied significantly. The most dominant Archaeal OTUs were Methanosarcina and Methanobacterium. The Bacterial community was dominated by the phyla Bacteroidetes, Firmicutes and Synergistes.

No correlation was observed between methane production rate and the common biomass descriptors of digester biomass concentrations (VSS), microbial richness, Shannon Weaver diversity and evenness indices. However, the relative abundance values of 10 OTUs including one Archaeal and nine Bacterial taxa were found to

Water Research, Vol 110 (March 2017): pg. 161-169. DOI. This article is @ Elsevier and permission has been granted for this version to appear in e-Publications@Marquette. Elsevier does not grant permission for this article to be further copied/distributed or hosted elsewhere without the express permission from Elsevier. 
significantly correlate with digester methane production rate. Seven OTUs positively correlated and the remaining three negatively correlated to digester methane production rate. The relative abundance values of the 10 OTUs were used as descriptors to develop a MLR equation demonstrating good predictability of digester methane production rate. Apart from a methanogen (Methanosarcina) and a syntrophic acetogen (Syntrophomonas), the 10 descriptors also included fermenters (acidogens). To the author's knowledge, this is the first report of a quantitative, predictive correlation between digester quasi steady state methane production rate and microbial community descriptors.

Future research with multiple biomass samples subjected to factors that are known to influence digester microbial community and their activity, such as different wastewater composition, $\mathrm{pH}$, temperature, digester configuration and OLR, in combination with high-throughput sequencing and conventional approaches for kinetic study, could advance development of more robust QSAR models that could be incorporated into existing $A D$ models to improve predictability.

\section{Acknowledgements}

The authors thank Mike Dollhopf (Water Quality Center, Marquette University, Milwaukee USA) and Dr. Jean-Philippe Steyer (Laboratory of Environmental Biotechnology, Narbonne, France) for their contributions to this work.

\section{References}

Altschul et al., 1990. S.F. Altschul, W. Gish, W. Miller, E.W. Myers, D.J. Lipman. Basic local alignment search tool. J. Mol. Biol., 215 (3) (1990), pp. 403-410 http://dx.doi.org/10.1016/S00222836(05)80360-2

APHA et al., 1998. American Public Health Association (APHA), American Water Works Association (AWWA), Water Environment Federation (WEF), et al. Standard Methods for the Examination of Water and Wastewater. (twentieth ed.) American Public Health Association (1998) ISBN: 0875532357

Angenent et al., 2004. L.T. Angenent, K. Karim, M.H. Al-Dahhan, B.A. Wrenn, R. Domíguez-Espinosa. Production of bioenergy and biochemicals from

Water Research, Vol 110 (March 2017): pg. 161-169. DOI. This article is (C) Elsevier and permission has been granted for this version to appear in e-Publications@Marquette. Elsevier does not grant permission for this article to be further copied/distributed or hosted elsewhere without the express permission from Elsevier. 
NOT THE PUBLISHED VERSION; this is the author's final, peer-reviewed manuscript. The published version may be accessed by following the link in the citation at the bottom of the page.

industrial and agricultural wastewater. Trends Biotechnol., 22 (9) (2004), pp. 477-485 http://dx.doi.org/10.1016/j.tibtech.2004.07.001 Ariunbaatar et al., 2014. J. Ariunbaatar, A. Panico, G. Esposito, F. Pirozzi, P.N.L. Lens. Pretreatment methods to enhance anaerobic digestion of organic solid waste. Appl. Energy, 123 (2014), pp. 143-156 http://dx.doi.org/10.1016/j.apenergy.2014.02.035

Baena et al., 1998. S. Baena, M.L. Fardeau, M. Labat, B. Ollivier, P. Thomas, J.L. Garcia, B.K.C. Patel. Aminobacterium colombiense gen. nov. sp. nov., an amino acid-degrading anaerobe isolated from anaerobic sludge. Anaerobe, 4 (1998), pp. 241-250 http://dx.doi.org/10.1006/anae.1998.0170

Baena et al., 2000. S. Baena, M.L. Fardeau, M. Labat, B. Ollivier, J.L. Garcia, B.K. Patel. Aminobacterium mobile sp. Nov., a new anaerobic aminoacid-degrading bacterium. Int. J. Syst. Evol. Microbiol., 50 (1) (2000), pp. 259-264 http://dx.doi.org/10.1099/00207713-50-1-259

Batstone et al., 2002. D.J. Batstone, J. Keller, I. Angelidaki, S.V. Kalyuzhnyi, S.G. Pavlostathis, A. Rozzi, W.T. Sanders, H. Siegrist, V.A. Vavilin. The IWA anaerobic digestion model No 1 (ADM1). Water Sci. Technol., 45 (10) (2002), pp. 65-73 ISBN: 1900222787

Bocher et al., 2015. B.T.W. Bocher, K. Cherukuri, J.S. Maki, M. Johnson, D.H. Zitomer. Relating methanogen community structure and anaerobic digester function. Water Res., 70 (2015), pp. 425-435 http://dx.doi.org/10.1016/j.watres.2014.12.018

Braun et al., 2015. F. Braun, J. Hamelin, A. Bonnafous, N. Delgenès, J.P. Steyer, D. Patureau. Similar PAH fate in anaerobic digesters inoculated with three microbial communities accumulating either volatile fatty acids or methane. PLoS One, 10 (4) (2015), pp. 1-20

http://dx.doi.org/10.1371/journal.pone.0125552

Briones et al., 2007. A.M. Briones, B.J. Daugherty, L.T. Angenent, K.D. Rausch, M.E. Tumbleson, L. Raskin. Microbial diversity and dynamics in multi and single-compartment anaerobic bioreactors processing sulfate rich waste streams. Environ. Microbiol., 9 (1) (2007), pp. 93106 http://dx.doi.org/10.1111/j.1462-2920.2006.01119.x

Carballa et al., 2011. M. Carballa, M. Smits, C. Etchebehere, N. Boon, W. Verstraete. Correlations between molecular and operational parameters in continuous lab-scale anaerobic reactors. Appl. Microbiol. Biotechnol., 89 (2) (2011), pp. 303-314 http://dx.doi.org/10.1007/s00253-010-2858-y

Carey et al., 2016. D.E. Carey, D.H. Zitomer, K.R. Hristova, A.D. Kappell, P.J. McNamara. Triclocarban influences antibiotic resistance and alters anaerobic digester microbial community structure. American Chemical Society Environ. Sci. Technol., 50 (1) (2016), pp. 126-134 http://dx.doi.org/10.1021/acs.est.5b03080

Water Research, Vol 110 (March 2017): pg. 161-169. DOI. This article is @ Elsevier and permission has been granted for this version to appear in e-Publications@Marquette. Elsevier does not grant permission for this article to be further copied/distributed or hosted elsewhere without the express permission from Elsevier. 
NOT THE PUBLISHED VERSION; this is the author's final, peer-reviewed manuscript. The published version may be accessed by following the link in the citation at the bottom of the page.

Chen et al., 2008. Y. Chen, J.J. Cheng, K.S. Creamer. Inhibition of anaerobic digestion process: a review. Bioresour. Technol., 99 (10) (2008), pp. 4044-4064 http://dx.doi.org/10.1016/j.biortech.2007.01.057

Conklin et al., 2006. A. Conklin, H.D. Stensel, J. Ferguson. Growth kinetics and competition between Methanosarcina and Methanosaeta in mesophilic anaerobic digestion. Water Environ. Res., 78 (5) (2006), pp. 486-496 ISSN: 1061-4303

Curtis et al., 2003. T.P. Curtis, I.M. Head, D.W. Graham. Theoretical engineering: ecology for biology. Environ. Sci. Technol. (2003), pp. 64-70 http://dx.doi.org/10.1021/es0323493

Enright et al., 2009. A.M. Enright, V. McGrath, D. Gill, G. Collins, V. O'Flaherty. Effect of seed sludge and operation conditions on performance and archaeal community structure of low-temperature anaerobic solvent-degrading bioreactors. Syst. Appl. Microbiol., 32 (1) (2009), pp. 65-79 http://dx.doi.org/10.1016/j.syapm.2008.10.003

Falk et al., 2009. M.W. Falk, K.G. Song, M.G. Matiasek, S. Wuertz. Microbial community dynamics in replicate membrane bioreactors - Natural reproducible fluctuations. Water Res., 43 (3) (2009), pp. 842-852 http://dx.doi.org/10.1016/j.watres.2008.11.021

Fernandez et al., 2000. A.S. Fernandez, S.A. Hashsham, S.L. Dollhopf, L. Raskin, O. Glagoleva, F.B. Dazzo, R.F. Hickey, C.S. Criddle, J.M. Tiedje. Flexible community structure correlates with stable community function in methanogenic bioreactor communities perturbed by glucose. Appl. Environ. Microbiol., 66 (9) (2000), pp. 4058-4067 http://dx.doi.org/10.1128/AEM.66.9.4058-4067.2000

Golbraikh and Tropsha, 2000. A. Golbraikh, A. Tropsha. Predictive QSAR modeling based on diversity sampling of experimental datasets for the training and test set selection. Mol. Divers., 5 (4) (2000), pp. 231-243 http://dx.doi.org/10.1023/A:1021372108686

Grabowski et al., 2005. A. Grabowski, B.J. Tindall, V. Bardin, D. Blanchet, C. Jeanthon. Petrimonas sulfuriphila gen. nov., sp. nov., a mesophilic fermentative bacterium isolated from a biodegraded oil reservoir. Int. J. Syst. Evol. Microbiol., 55 (3) (2005), pp. 1113-1121 http://dx.doi.org/10.1099/ijs.0.63426-0

Hamdi et al., 2015. O. Hamdi, W.B. Hania, A. Postec, H. Bouallagui, M. Hamdi, P. Bonin, B. Ollivier, M.L. Fardeau. Aminobacterium thunnarium sp. nov., a mesophilic, amino acid-degrading bacterium isolated from an anaerobic sludge digester, pertaining to the phylum synergistetes. Int. J. Syst. Evol. Microbiol., 65 (2015), pp. 609-614 http://dx.doi.org/10.1099/ijs.0.068965-0

Hashsham et al., 2000. S.A. Hashsham, A.S. Fernandez, S.L. Dollhopf, F.B. Dazzo, R.F. Hickey, J.M. Tiedje, C.S. Criddle. Parallel processing of substrate correlates with greater functional stability in methanogenic

Water Research, Vol 110 (March 2017): pg. 161-169. DOI. This article is $(\subset)$ Elsevier and permission has been granted for this version to appear in e-Publications@Marquette. Elsevier does not grant permission for this article to be further copied/distributed or hosted elsewhere without the express permission from Elsevier. 
NOT THE PUBLISHED VERSION; this is the author's final, peer-reviewed manuscript. The published version may be accessed by following the link in the citation at the bottom of the page.

bioreactor communities perturbed by glucose. Appl. Environ.

Microbiol., 66 (9) (2000), pp. 4050-4057

http://dx.doi.org/10.1128/AEM.66.9.4050-4057.2000

Hori et al., 2006. T. Hori, S. Haruta, Y. Ueno, M. Ishii, Y. Igarashi. Dynamic transition of a methanogenic population in response to the concentration of volatile fatty acids in a thermophilic anaerobic digester dynamic transition of a methanogenic population in response to the concentration of volatile fatty acids in a thermophilic anaerobic digester. Appl. Environ. Microbiol., 72 (2) (2006), pp. 1623-1630 http://dx.doi.org/10.1128/AEM.72.2.1623

Karakashev et al., 2005 D. Karakashev, D.J. Batstone, I. Angelidaki. Influence of environmental conditions on methanogenic compositions in anaerobic biogas reactors. Appl. Environ. Microbiol., 71 (1) (2005), pp. 331-338 http://dx.doi.org/10.1128/AEM.71.1.331-338.2005

Konovalov et al., 2008. D.A. Konovalov, L.E. Llewellyn, Y.V. Heyden, D. Coomans. Robust cross-validation of linear regression QSAR models robust cross-validation of linear regression QSAR models. J. Chem. Inf. Model., 48 (2008), pp. 2081-2094 http://dx.doi.org/10.1021/ci800209k

Kozich et al., 2013. J.J. Kozich, S.L. Westcott, N.T. Baxter, S.K. Highlander, P.D. Schloss. Development of a dual-index sequencing strategy and curation pipeline for analyzing amplicon sequence data on the MiSeq Illumina sequencing platform. Appl. Environ. Microbiol., 79 (17) (2013), pp. 5112-5120 http://dx.doi.org/10.1128/AEM.01043-13

Leitão et al., 2006. R.C. Leitão, A.C. van Haandel, G. Zeeman, G. Lettinga. The effects of operational and environmental variations on anaerobic wastewater treatment systems: a review. Bioresour. Technol., 97 (9) (2006), pp. 1105-1118 http://dx.doi.org/10.1016/j.biortech.2004.12.007

Liu and Whitman, 2008. Y. Liu, W.B. Whitman. Metabolic, phylogenetic, and ecological diversity of the methanogenic Archaea. Ann. N. Y. Acad. Sci., 1125 (2008), pp. 171-189 http://dx.doi.org/10.1196/annals.1419.019

Lü et al., 2009. F. Lü, L.M. Shao, V. Bru, J.J. Godon, P.J. He. Synergetic effect of $\mathrm{pH}$ and biochemical components on bacterial diversity during mesophilic anaerobic fermentation of biomass-origin waste. J. Appl. Microbiol., 106 (2) (2009), pp. 580-591 http://dx.doi.org/10.1111/j.1365-2672.2008.04029.x

Mata-Alvarez et al., 2000. J. Mata-Alvarez, S. Macé, P. Llabrés. Anaerobic digestion of organic solid wastes. An overview of research achievements and perspectives. Bioresour. Technol., 74 (1) (2000), pp. 3-16 http://dx.doi.org/10.1016/S0960-8524(00)00023-7

Water Research, Vol 110 (March 2017): pg. 161-169. DOI. This article is $(\subset)$ Elsevier and permission has been granted for this version to appear in e-Publications@Marquette. Elsevier does not grant permission for this article to be further copied/distributed or hosted elsewhere without the express permission from Elsevier. 
Morris et al., 2014. R. Morris, A.S. Gimenez, U. Bhattad, C. Kearney, C.A. Struble, D.H. Zitomer, J.S. Maki. Methyl coenzyme M reductase (mcrA) gene abundance correlates with activity measurements of methanogenic $\mathrm{H}_{2} / \mathrm{CO}_{2}$ enriched anaerobic biomass. Microb. Biotechnol., 7 (1) (2014), pp. 77-84 http://dx.doi.org/10.1111/1751-7915.12094

Nirmalakhandan and Speece, 1988. N.N. Nirmalakhandan, R.E. Speece. Structure-activity relationships Quantitative techniques for predicting the behavior of chemicals in the ecosystem. Environ. Sci. Technol., 22 (6) (1988), pp. 606-615 http://dx.doi.org/10.1021/es00171a002

Noike et al., 1985. T. Noike, G. Endo, J.E. Chang, J. Yaguchi, J. Matsumoto. Characteristics of carbohydrate degradation and the rate-limiting step in anaerobic digestion. Biotechnol. Bioeng., 27 (10) (1985), pp. 14821489 http://dx.doi.org/10.1002/bit.260271013

Novotny et al., 2010. V. Novotny, J. Ahern, P. Brown. Water Centric

Sustainable Communities: Planning, Retrofitting and Building the Next Urban Environment. John Wiley \& Sons, Hoboken, NJ (2010) ISBN: 047064284X

Ogbonna et al., 2015. C.B. Ogbonna, D.P. Berebon, E.K. Onwuegbu. Relationship between temperature, $\mathrm{pH}$ and population of selected microbial indicators during anaerobic digestion of Guinea grass (Panicum Maximum). Am. J. Microbiol. Res., 3 (1) (2015), pp. 14-24 http://dx.doi.org/10.12691/ajmr-3-1-3

Oksanen et al., 2016. J. Oksanen, F.G. Blanchet, R. Kindt, P. Legendre, P.R. Minchin, R.B. O'Hara, G.L. Simpson, P. Solymos, M. Henry, H. Stevens, $\mathrm{H}$. Wagner. Vegan: Community Ecology Package. $R$ Package Version 2.3-4 (2016)

R Core Team, 2015. R Core Team. R: A Language and Environment for Statistical Computing. R Foundation for Statistical Computing, Vienna, Austria (2015) URL https://www.R-project.org/

Ramirez et al., 2009. I. Ramirez, E.I.P. Volcke, R. Rajinikanth, J.P. Steyer. Modeling microbial diversity in anaerobic digestion through an extended ADM1 model. Water Res., 43 (11) (2009), pp. 2787-2800 http://dx.doi.org/10.1016/j.watres.2009.03.034

Resende et al., 2015. J.A. Resende, J.J. Godon, A. Bonnafous, P.B. Arcuri, V.L. Silva, M.H. Otenio, C.G. Diniz. Seasonal variation on microbial community and methane production during anaerobic digestion of cattle manure in Brazil. Microb. Ecol. (2015), pp. 735-746 http://dx.doi.org/10.1007/s00248-015-0647-y

Rivière et al., 2009. D. Rivière, V. Desvignes, E. Pelletier, S. Chaussonnerie, S. Guermazi, J. Weissenbach, T. Li, P. Camacho, A. Sghir. Towards the definition of a Core of microorganisms involved in anaerobic digestion of sludge. ISME J., 3 (6) (2009), pp. 700-714 http://dx.doi.org/10.1038/ismej.2009.2

Water Research, Vol 110 (March 2017): pg. 161-169. DOI. This article is $(\subset)$ Elsevier and permission has been granted for this version to appear in e-Publications@Marquette. Elsevier does not grant permission for this article to be further copied/distributed or hosted elsewhere without the express permission from Elsevier. 
Schloss et al., 2009. P.D. Schloss, S.L. Westcott, T. Ryabin, J.R. Hall, M. Hartmann, E.B. Hollister, C.F. Weber. Introducing mothur: opensource, platform-independent, community-supported software for describing and comparing microbial communities. Appl. Environ. Microbiol., 75 (23) (2009), pp. 7537-7541 http://dx.doi.org/10.1128/AEM.01541-09

Schüürmann et al., 2008. G. Schüürmann, R.U. Ebert, J. Chen, B. Wang, R. Kühne. External validation and prediction employing the predictive squared correlation coefficient test set activity mean vs training set activity mean. American Chemical Society J. Chem. Inf. Model., 48 (11) (2008), pp. 2140-2145 http://dx.doi.org/10.1021/ci800253u

Shah and Collins, 1988. H.N. Shah, M.D. Collins. Proposal for reclassification of Bacteroides asaccharolyticus, Bacteroides gingivalis, and Bacteroides endodontalis in a new genus, Porphyromonas. Int. J. Syst. Bacteriol., 38 (1) (1988), pp. 128-131 http://dx.doi.org/10.1099/00207713-38-1-128

Shiratori et al., 2008. H. Shiratori, H. Ohiwa, H. Ikeno, S. Ayame, N. Kataoka, A. Miya, T. Beppu, K. Ueda. Lutispora thermophila gen. nov., sp. nov., a thermophilic, spore-forming bacterium isolated from a thermophilic methanogenic bioreactor digesting municipal solid wastes. Int. J. Syst. Evol. Microbiol., 58 (4) (2008), pp. 964-969 http://dx.doi.org/10.1099/ijs.0.65490-0

Speece, 2008. R.E. Speece. Anaerobic biotechnology and odor/corrosion control for municipalities and industries. Fields Publishing, Inc, Nashville, TN (2008) ISBN: 1-57843-052-9

Stiles and Holzapfel, 1997. M.E. Stiles, W.H. Holzapfel. Lactic acid bacteria of foods and their current taxonomy. Int. J. Food Microbiol., 36 (1) (1997), pp. 1-29 http://dx.doi.org/10.1016/S0168-1605(96)01233-0

Sundberg et al., 2013. C. Sundberg, W.A. Al-Soud, M. Larsson, E. Alm, S.S. Yekta, B.H. Svensson, S.J. Sørensen, A. Karlsson. 454 pyrosequencing analyses of bacterial and archaeal richness in 21 full-scale biogas digesters. FEMS Microbiol. Ecol., 85 (3) (2013), pp. 612-626 http://dx.doi.org/10.1111/1574-6941.12148

Tale et al., 2011. V.P. Tale, J.S. Maki, C.A. Struble, D.H. Zitomer. Methanogen community structure-activity relationship and bioaugmentation of overloaded anaerobic digesters. Water Res., 45 (16) (2011), pp. 5249-5256 http://dx.doi.org/10.1016/j.watres.2011.07.035

Tale et al., 2015. V.P. Tale, J.S. Maki, D.H. Zitomer. Bioaugmentation of overloaded anaerobic digesters restores function and archaeal community. Water Res., 70 (2015), pp. 138-147 http://dx.doi.org/10.1016/j.watres.2014.11.037

Water Research, Vol 110 (March 2017): pg. 161-169. DOI. This article is @ Elsevier and permission has been granted for this version to appear in e-Publications@Marquette. Elsevier does not grant permission for this article to be further copied/distributed or hosted elsewhere without the express permission from Elsevier. 
Tian et al., 2014. Z. Tian, L. Cabrol, G. Ruiz-Filippi, P. Pullammanappallil. Microbial ecology in anaerobic digestion at agitated and non-agitated conditions. PloS One, 9 (10) (2014), p. e109769 http://dx.doi.org/10.1371/journal.pone.0109769

Treu et al., 2016. L. Treu, P.G. Kougias, S. Campanaro, I. Bassani, I. Angelidaki. Deeper insight into the structure of the anaerobic digestion microbial community; the biogas microbiome database is expanded with 157 new genomes. Bioresour. Technol., 216 (2016), pp. 260-266 http://dx.doi.org/10.1016/j.biortech.2016.05.081 September van Loosdrecht and Brdjanovic, 2014. M.C.M. van Loosdrecht, D. Brdjanovic. Water treatment. Anticipating the next century of wastewater treatment. Science, 344 (6191) (2014), pp. 1452-1453 http://dx.doi.org/10.1126/science.1255183

Venkiteshwaran et al., 2015. K. Venkiteshwaran, B. Bocher, J. Maki, D. Zitomer. Relating anaerobic digestion microbial community and process function. Libertas Academica Microbiol. Insights, 8 (Suppl. 2) (2015), pp. 37-44 http://dx.doi.org/10.4137/MBI.S33593

Venkiteshwaran et al., 2016. K. Venkiteshwaran, K. Milferstedt, J. Hamelin, D. Zitomer. Anaerobic digester bioaugmentation influences quasi steady state performance and microbial community. Water Res., 104 (2016), pp. 128-136 http://dx.doi.org/10.1016/j.watres.2016.08.012

Vidal, 2000. G. Vidal. Influence of the content in fats and proteins on the anaerobic biodegradability of dairy wastewaters. Bioresour. Technol., 74 (3) (2000), pp. 231-239 http://dx.doi.org/10.1016/S0960$8524(00) 00015-8$

Wang and Qian, 2009. Y. Wang, P.Y. Qian. Conservative fragments in bacterial 16S rRNA genes and primer design for $16 \mathrm{~S}$ ribosomal DNA amplicons in metagenomic studies. PloS One, 4 (10) (2009), p. e7401 http://dx.doi.org/10.1371/journal.pone.0007401

Werner et al., 2011. J.J. Werner, D. Knights, M.L. Garcia, N.B. Scalfone, Samual Smith, Kevin Yarasheski, Theresa a Cummings, Allen R. Beers, Rob Knight, Largus T. Angenent. Bacterial community structures are unique and resilient in full-scale bioenergy systems. Proc. Natl. Acad. Sci. U. S. A., 108 (10) (2011), pp. 4158-4163 http://dx.doi.org/10.1073/pnas.1015676108

Westermann et al., 1989. P. Westermann, B.K. Ahring, R.A. Mah. Threshold acetate concentrations for acetate catabolism by aceticlastic methanogenic bacteria. Appl. Environ. Microbiol., 55 (2) (1989), pp. 514-515 ISSN: 0099-2240

Zuur et al., 2007. A. Zuur, E.N. Ieno, G.M. Smith. Analysing Ecological Data. Springer Science \& Business Media, New York, NY (2007) ISBN: 0387459723

Water Research, Vol 110 (March 2017): pg. 161-169. DOI. This article is $(\subset)$ Elsevier and permission has been granted for this version to appear in e-Publications@Marquette. Elsevier does not grant permission for this article to be further copied/distributed or hosted elsewhere without the express permission from Elsevier. 
NOT THE PUBLISHED VERSION; this is the author's final, peer-reviewed manuscript. The published version may be accessed by following the link in the citation at the bottom of the page.

\section{Appendix A. Supplementary data}

The following are the supplementary data related to this article:

Water Research, Vol 110 (March 2017): pg. 161-169. DOI. This article is $(\subset)$ Elsevier and permission has been granted for this version to appear in e-Publications@Marquette. Elsevier does not grant permission for this article to be further copied/distributed or hosted elsewhere without the express permission from Elsevier. 
Table S1: Seed biomass source data

\begin{tabular}{|c|c|c|}
\hline Digester ID & Waste treated at seed source & Digester configuration* \\
\hline Alaska (AK) & Municipal sludge & CSTR \\
\hline Alabama ( $\mathrm{AL})$ & Petrochemical & UASB \\
\hline Arkansas (AR) & Food waste & UASB \\
\hline Arizona (AZ) & Municipal sludge & CSTR \\
\hline California (CA) & Winery & CSTR \\
\hline Colorado (CO) & Brewery & UASB \\
\hline Connecticut (CT) & Municipal sludge & CSTR \\
\hline Delaware (DE) & Municipal \& industrial WW mix & CSTR \\
\hline Florida (FL) & Municipal sludge & CSTR \\
\hline Georgia (GA) & Municipal sludge & CSTR \\
\hline Hawaii (HI) & Municipal sludge & CSTR \\
\hline Iowa (IA) & Confections manufacture & CSTR \\
\hline Idaho (ID) & Ethanol & UASB \\
\hline Illinois (IL) & Food \& beverage & CSTR \\
\hline Indiana (IN) & Corn mill & CSTR \\
\hline Kansas (KS) & Soda bottling & UASB \\
\hline Kentucky (KY) & Cracker \& cereal & CSTR \\
\hline Louisiana (LA) & Food waste & CSTR \\
\hline Massachusetts (MA) & Food waste & CSTR \\
\hline Maryland (MD) & Yeast & CSTR \\
\hline Maine (ME) & Municipal sludge \& industrial WW mix & CSTR \\
\hline Michigan ( MI) & Municipal sludge \& paper & CSTR \\
\hline Minnesota (MN) & Paper & CSTR \\
\hline Missouri (MO) & Food waste & CSTR \\
\hline Mississippi (MS) & Municipal sludge & CSTR \\
\hline Montana (MT) & Municipal sludge & CSTR \\
\hline North Carolina (NC) & Municipal sludge & CSTR \\
\hline North Dakota (ND) & Beet sugar \& yeast & CSTR \\
\hline Nebraska (NE) & Municipal sludge & CSTR \\
\hline New Hampshire (NH) & Dairy & CSTR \\
\hline New Jersey (NJ) & Food waste & CSTR \\
\hline New Mexico (NM) & Dairy & CSTR \\
\hline Nevada (NV) & Municipal sludge & CSTR \\
\hline New York (NY) & Dairy & CSTR \\
\hline Ohio $(\mathrm{OH})$ & Municipal sludge & CSTR \\
\hline Oklahoma (OK) & Soybean process waste & CSTR \\
\hline Oregon (OR) & Municipal sludge & CSTR \\
\hline Pennsylvania (PA) & Dairy & CSTR \\
\hline South Carolina (SC) & Municipal sludge $\&$ fruit juice & CSTR \\
\hline
\end{tabular}




\begin{tabular}{|c|c|c|}
\hline South Dakota (SD) & Municipal sludge & CSTR \\
\hline Tennessee (TN) & Municipal sludge & CSTR \\
\hline Texas (TX) & Cheese whey & AnMBR \\
\hline Utah (UT) & Municipal sludge & CSTR \\
\hline Virginia (VA) & Municipal sludge & CSTR \\
\hline Vermont (VT) & Brewery & CSTR \\
\hline Washington (WA) & Municipal sludge & CSTR \\
\hline Wisconsin A (WI A) & Brewery & CSTR \\
\hline Wisconsin B (WI B) & Municipal sludge & CSTR \\
\hline West Virginia (WV) & Municipal sludge & CSTR \\
\hline Wyoming (WY) & Municipal sludge & \\
\hline
\end{tabular}

*CSTR - Completely stirred type reactor, UASB - Upflow anaerobic sludge blanket, AnMBR Anaerobic membrane reactor 
Table S2: Observed methane production (L-CH4/LR-day) rate in 149 digesters. The functional parameters of the digesters were analyzed for 7 consecutive days and the table reports the average and standard deviation of those 7 data points. The digesters were classified in to three equally sized group (High, Medium and Low) based on their methane production rate. 50 highest methane producing digesters were classified as "High", the next 50 digesters were classified as "Medium" and the remaining lowest methane producing digesters were classified as "Low".

\begin{tabular}{|c|c|c|c|c|c|c|c|}
\hline \multirow[t]{2}{*}{$\begin{array}{c}\text { Digest } \\
\text { er } \\
\text { ID }\end{array}$} & \multicolumn{2}{|c|}{$\begin{array}{c}\text { Methane production } \\
\text { rate } \\
\text { (L-CH4/LR-day) }\end{array}$} & \multirow[t]{2}{*}{$\begin{array}{c}\text { Classificati } \\
\text { on }\end{array}$} & \multirow[t]{2}{*}{$\begin{array}{l}\text { Digest } \\
\text { er } \\
\text { ID }\end{array}$} & \multicolumn{2}{|c|}{$\begin{array}{c}\text { Methane production } \\
\text { rate } \\
(\mathrm{L}-\mathrm{CH} 4 / \mathrm{LR}-\mathrm{day})\end{array}$} & \multirow[t]{2}{*}{$\begin{array}{c}\text { Classificati } \\
\text { on }\end{array}$} \\
\hline & Average & Std. dev & & & Average & Std. dev & \\
\hline AK1 & 0.32 & 0.02 & Medium & MT1 & 0.59 & 0.01 & High \\
\hline AK2 & 0.33 & 0.03 & Medium & MT2 & 0.70 & 0.08 & High \\
\hline AK3 & 0.39 & 0.03 & Medium & MT3 & 0.56 & 0.03 & High \\
\hline AL1 & 0.43 & 0.02 & Medium & NC1 & 0.37 & 0.02 & Medium \\
\hline AL2 & 0.49 & 0.03 & Medium & NC2 & 0.21 & 0.01 & Low \\
\hline AL3 & 0.54 & 0.03 & High & NC3 & 0.64 & 0.03 & High \\
\hline AR1 & 0.24 & 0.03 & Low & ND2 & 0.55 & 0.02 & High \\
\hline AR2 & 0.24 & 0.03 & Low & ND3 & 0.52 & 0.02 & Medium \\
\hline AR3 & 0.27 & 0.03 & Medium & NE1 & 0.43 & 0.01 & Medium \\
\hline$A Z 1$ & 0.50 & 0.03 & Medium & NE2 & 0.46 & 0.02 & Medium \\
\hline$A Z 2$ & 0.40 & 0.04 & Medium & NE3 & 0.36 & 0.01 & Medium \\
\hline AZ3 & 0.35 & 0.05 & Medium & $\mathrm{NH} 1$ & 0.15 & 0.01 & Low \\
\hline CA1 & 0.65 & 0.06 & High & $\mathrm{NH} 2$ & 0.15 & 0.01 & Low \\
\hline CA2 & 0.73 & 0.06 & High & $\mathrm{NH3}$ & 0.14 & 0.02 & Low \\
\hline CA3 & 0.66 & 0.06 & High & NJ1 & 0.12 & 0.01 & Low \\
\hline $\mathrm{CO} 1$ & 0.63 & 0.05 & High & NJ2 & 0.13 & 0.01 & Low \\
\hline $\mathrm{CO} 2$ & 0.60 & 0.04 & High & NJ3 & 0.11 & 0.01 & Low \\
\hline $\mathrm{CO} 3$ & 0.48 & 0.04 & Medium & NM1 & 0.50 & 0.07 & Medium \\
\hline CT1 & 0.17 & 0.02 & Low & NM2 & 0.58 & 0.03 & High \\
\hline CT2 & 0.28 & 0.12 & Medium & NM3 & 0.63 & 0.05 & High \\
\hline CT3 & 0.48 & 0.12 & Medium & NV1 & 0.13 & 0.02 & Low \\
\hline DE1 & 0.15 & 0.01 & Low & NV2 & 0.13 & 0.01 & Low \\
\hline DE2 & 0.16 & 0.01 & Low & NV3 & 0.13 & 0.01 & Low \\
\hline DE3 & 0.29 & 0.02 & Medium & NY1 & 0.17 & 0.02 & Low \\
\hline FL1 & 0.69 & 0.05 & High & NY2 & 0.16 & 0.02 & Low \\
\hline FL2 & 0.67 & 0.01 & High & NY3 & 0.18 & 0.01 & Low \\
\hline FL3 & 0.67 & 0.01 & High & $\mathrm{OH} 1$ & 0.41 & 0.03 & Medium \\
\hline GA1 & 0.32 & 0.04 & Medium & $\mathrm{OH} 2$ & 0.39 & 0.05 & Medium \\
\hline GA2 & 0.13 & 0.02 & Low & $\mathrm{OH} 3$ & 0.38 & 0.04 & Medium \\
\hline GA3 & 0.12 & 0.01 & Low & OK1 & 0.66 & 0.04 & High \\
\hline HI1 & 0.38 & 0.02 & Medium & OK2 & 0.73 & 0.06 & High \\
\hline HI2 & 0.61 & 0.04 & High & OK3 & 0.81 & 0.05 & High \\
\hline HI3 & 0.36 & 0.02 & Medium & OR1 & 0.26 & 0.02 & Low \\
\hline
\end{tabular}




\begin{tabular}{|c|c|c|c|c|c|c|c|}
\hline IA1 & 0.57 & 0.04 & High & OR2 & 0.58 & 0.04 & High \\
\hline IA2 & 0.58 & 0.04 & High & OR3 & 0.41 & 0.03 & Medium \\
\hline IA3 & 0.62 & 0.06 & High & PA1 & 0.63 & 0.08 & High \\
\hline ID1 & 0.30 & 0.02 & Medium & PA2 & 0.52 & 0.03 & Medium \\
\hline ID2 & 0.33 & 0.03 & Medium & PA3 & 0.71 & 0.10 & High \\
\hline ID3 & 0.32 & 0.02 & Medium & SC1 & 0.50 & 0.09 & Medium \\
\hline IL1 & 0.63 & 0.07 & High & SC2 & 0.51 & 0.02 & Medium \\
\hline IL2 & 0.67 & 0.07 & High & SC3 & 0.68 & 0.06 & High \\
\hline IL3 & 0.67 & 0.06 & High & SD1 & 0.20 & 0.03 & Low \\
\hline IN1 & 0.56 & 0.04 & High & SD2 & 0.17 & 0.02 & Low \\
\hline IN2 & 0.49 & 0.04 & Medium & SD3 & 0.25 & 0.02 & Low \\
\hline IN3 & 0.52 & 0.04 & Medium & TNS1 & 0.48 & 0.05 & Medium \\
\hline KS1 & 0.98 & 0.05 & High & TNS2 & 0.63 & 0.12 & High \\
\hline KS2 & 0.92 & 0.06 & High & TNS3 & 0.63 & 0.04 & High \\
\hline KS3 & 0.56 & 0.04 & High & TX1 & 0.50 & 0.04 & Medium \\
\hline KY1 & 0.69 & 0.07 & High & TX2 & 0.35 & 0.01 & Medium \\
\hline KY2 & 0.57 & 0.07 & High & TX3 & 0.45 & 0.02 & Medium \\
\hline KY3 & 0.61 & 0.05 & High & UT1 & 0.09 & 0.004 & Low \\
\hline LA1 & 0.20 & 0.02 & Low & UT2 & 0.10 & 0.01 & Low \\
\hline LA2 & 0.43 & 0.02 & Medium & UT3 & 0.11 & 0.01 & Low \\
\hline LA3 & 0.57 & 0.01 & High & VA1 & 0.25 & 0.01 & Low \\
\hline MA1 & 0.35 & 0.04 & Medium & VA2 & 0.13 & 0.01 & Low \\
\hline MA2 & 0.13 & 0.03 & Low & VA3 & 0.13 & 0.01 & Low \\
\hline MA3 & 0.15 & 0.02 & Low & VT1 & 0.25 & 0.03 & Low \\
\hline MD1 & 0.54 & 0.07 & High & VT2 & 0.31 & 0.05 & Medium \\
\hline MD2 & 0.61 & 0.08 & High & VT3 & 0.27 & 0.03 & Low \\
\hline MD3 & 0.60 & 0.05 & High & WA1 & 0.63 & 0.08 & High \\
\hline ME1 & 0.16 & 0.02 & Low & WA2 & 0.57 & 0.08 & High \\
\hline ME2 & 0.15 & 0.01 & Low & WA3 & 0.59 & 0.06 & High \\
\hline ME3 & 0.16 & 0.02 & Low & WI A1 & 0.38 & 0.02 & Medium \\
\hline MI1 & 0.23 & 0.02 & Low & WI A2 & 0.56 & 0.04 & High \\
\hline MI2 & 0.23 & 0.03 & Low & WI A3 & 0.50 & 0.04 & Medium \\
\hline MI3 & 0.23 & 0.02 & Low & WI B1 & 0.51 & 0.02 & Medium \\
\hline MN1 & 0.25 & 0.03 & Low & WI B2 & 0.57 & 0.01 & High \\
\hline MN2 & 0.26 & 0.03 & Low & WI B3 & 0.62 & 0.04 & High \\
\hline MN3 & 0.25 & 0.02 & Low & WV1 & 0.23 & 0.02 & Low \\
\hline MO1 & 0.37 & 0.05 & Medium & WV2 & 0.23 & 0.02 & Low \\
\hline MO2 & 0.33 & 0.02 & Medium & WV3 & 0.19 & 0.01 & Low \\
\hline MO3 & 0.47 & 0.05 & Medium & WY1 & 0.26 & 0.01 & Low \\
\hline MS1 & 0.54 & 0.05 & High & WY2 & 0.32 & 0.04 & Medium \\
\hline MS2 & 0.47 & 0.12 & Medium & WY3 & 0.13 & 0.01 & Low \\
\hline
\end{tabular}




\begin{tabular}{|l|l|}
\hline & \\
\hline
\end{tabular}


Table S3: Highly significant OTUs determined by initial screening.

50 iterations of Spearman's rank analysis were performed, where 75 out of 149 digesters where randomly selected and correlated with digester methane production rate. The value column " $N$ " represents the number of times the OTU was observed as the top ten positively or negatively correlated out of the total 50 iterations. $N=50$ represents $100 \%$ observation. The 7 OTUs in Table S3A and 3 OTUs in Table S3B, were observed to be positively and negatively correlated to methane production rate in 38 out of the 50 iterations ( $>75 \%$ of the iterations). These 10 OTUs were selected for the subsequent MLR analysis.

\begin{tabular}{|c|c|c|c|c|c|}
\hline \multicolumn{7}{|c|}{ (A) Relative abundance positively correlated to methane production } \\
\hline OTU ID & Class & Order & Family & Genus & N \\
\hline 1 & Bacteroidia & Bacteroidales & Porphyromonadaceae & Petrimonas & 50 \\
\hline 2 & Bacteroidia & Bacteroidales & Marinilabiaceae & unclassified & 50 \\
\hline 3 & Spirochaetes & Spirochaetales & PL-11B10 & unclassified & 50 \\
\hline 4 & Bacteroidia & Bacteroidales & M2PB4-65 termite group & unclassified & 46 \\
\hline 5 & Clostridia & Clostridiales & Syntrophomonadaceae & Syntrophomonas & 46 \\
\hline 6 & Methanomicrobia & Methanosarcinales & Methanosarcinaceae & Methanosarcina & 46 \\
\hline 7 & Clostridia & Clostridiales & Gracilibacteraceae & Lutispora & 40 \\
\hline
\end{tabular}

\begin{tabular}{|c|c|c|c|c|c|}
\hline \multicolumn{7}{|c|}{ (B) Relative abundance negatively correlated to methane production } \\
\hline OTU ID & Class & Order & Family & Genus & N \\
\hline 8 & Bacteroidia & Bacteroidales & Porphyromonadaceae & Porphyromonas & 50 \\
\hline 9 & Clostridia & Clostridiales & Ruminococcaceae & unclassified & 50 \\
\hline 10 & Clostridia & Clostridiales & Lachnospiraceae & unclassified & 50 \\
\hline
\end{tabular}


Table S4: $\mathbf{R}$ square values from the cross correlation of the highly significant OTUs.

\begin{tabular}{|c|cccccccccc|}
\cline { 2 - 10 } \multicolumn{1}{c|}{} & OTU1 & OTU2 & OTU3 & OTU4 & OTU5 & OTU6 & OTU7 & OTU8 & OTU9 & OTU10 \\
\hline OTU1 & $\mathbf{1}$ & 0.19 & 0.06 & 0.096 & 0.087 & 0.23 & 0.02 & 0.18 & 0.077 & 0.093 \\
OTU2 & 0.19 & $\mathbf{1}$ & 0.04 & 0.003 & 0.03 & 0.17 & 0.012 & 0.069 & 0.033 & 0.044 \\
OTU3 & 0.06 & 0.04 & $\mathbf{1}$ & 0.022 & 0.059 & 0.17 & 0.038 & 0.078 & 0.042 & 0.045 \\
OTU4 & 0.096 & 0.003 & 0.022 & $\mathbf{1}$ & 0.03 & 0.02 & 0.001 & 0.07 & 0.047 & 0.03 \\
OTU5 & 0.087 & 0.03 & 0.059 & 0.03 & $\mathbf{1}$ & 0.17 & 0.34 & 0.044 & 0.03 & 0.05 \\
OTU6 & 0.23 & 0.17 & 0.17 & 0.02 & 0.17 & $\mathbf{1}$ & 0.012 & 0.13 & 0.07 & 0.07 \\
OTU7 & 0.02 & 0.012 & 0.038 & 0.001 & 0.34 & 0.012 & $\mathbf{1}$ & 0.013 & 0.007 & 0.0067 \\
OTU8 & 0.18 & 0.069 & 0.078 & 0.07 & 0.044 & 0.13 & 0.013 & $\mathbf{1}$ & 0.047 & 0.003 \\
OTU9 & 0.077 & 0.033 & 0.042 & 0.047 & 0.03 & 0.07 & 0.007 & 0.047 & $\mathbf{1}$ & 0.088 \\
OTU10 & 0.093 & 0.044 & 0.045 & 0.03 & 0.05 & 0.07 & 0.0067 & 0.003 & 0.088 & $\mathbf{1}$ \\
\hline
\end{tabular}


Table S5: Test and training groups for the $\mathbf{1 0}$ validation tests.

Validation tests indicating (A) test and training groups employed and (B) identities of digesters employed for each iteration.

\begin{tabular}{|c|c|c|}
\hline (A) & Test set \\
\hline $\begin{array}{c}\text { Validation } \\
\text { test number }\end{array}$ & $\begin{array}{c}\text { Training set } \\
\text { group number } \\
\text { group numbers }\end{array}$ \\
\hline 1 & 10 & 1 to 9 \\
\hline 2 & 9 & 1 to $8 \& 10$ \\
\hline 3 & 8 & 1 to $7,9 \& 10$ \\
\hline 4 & 7 & 1 to $6 \& 8$ to 10 \\
\hline 5 & 6 & 1 to $5 \& 7$ to 10 \\
\hline 6 & 5 & 1 to $4 \& 6$ to 10 \\
\hline 7 & 4 & 1 to $3 \& 5$ to 10 \\
\hline 8 & 3 & $1,2 \& 4$ to 10 \\
\hline 9 & 2 & $1 \& 3$ to 10 \\
\hline 10 & 1 & 2 to 10 \\
\hline
\end{tabular}

\begin{tabular}{|c|c|c|c|c|c|c|c|c|c|}
\hline (B) & & & & & & & & & \\
\hline $\begin{array}{c}\text { Group } \\
1\end{array}$ & $\begin{array}{c}\text { Group } \\
2\end{array}$ & $\begin{array}{c}\text { Group } \\
\mathbf{3}\end{array}$ & $\begin{array}{c}\text { Group } \\
4\end{array}$ & $\begin{array}{c}\text { Group } \\
5\end{array}$ & $\begin{array}{c}\text { Group } \\
6\end{array}$ & $\begin{array}{c}\text { Group } \\
7\end{array}$ & $\begin{array}{c}\text { Group } \\
8\end{array}$ & $\begin{array}{c}\text { Group } \\
9\end{array}$ & $\begin{array}{c}\text { Group } \\
10\end{array}$ \\
\hline \multicolumn{10}{|c|}{ Digester ID } \\
\hline AL3 & ID2 & AL1 & CT1 & AK2 & AK1 & $\mathrm{CO} 2$ & AL2 & NJ1 & AR1 \\
\hline CT2 & ID3 & FL2 & GA3 & CT3 & AK3 & HI3 & AR3 & NY3 & AR2 \\
\hline FL1 & MD3 & ID1 & HI2 & DE2 & AZ2 & IL3 & IN3 & $\mathrm{OH} 2$ & AZ1 \\
\hline IL1 & MO1 & KS3 & IA3 & IN1 & CA2 & KY2 & KS2 & $\mathrm{OH} 3$ & AZ3 \\
\hline IL2 & MO2 & KY1 & KS1 & IN2 & CA3 & LA3 & KY3 & OK1 & CA1 \\
\hline MI3 & NE2 & ME2 & LA1 & LA2 & $\mathrm{CO} 1$ & MD1 & MA1 & OK3 & DE1 \\
\hline NC2 & NE3 & MI2 & MI1 & MA3 & $\mathrm{CO} 3$ & MS3 & ME1 & OR1 & DE3 \\
\hline NE1 & $\mathrm{NH} 1$ & MT3 & MN2 & MD2 & GA1 & NC1 & MT1 & SD2 & FL3 \\
\hline $\mathrm{OH} 1$ & OK2 & NJ3 & NC3 & MN1 & GA2 & ND2 & MT2 & VA2 & HI1 \\
\hline SC2 & OR2 & NY1 & ND3 & MO3 & MA2 & NV2 & NM3 & VA3 & IA1 \\
\hline TX3 & TNS1 & SC3 & $\mathrm{NH3}$ & MS1 & MS2 & NY2 & PA2 & VT2 & IA2 \\
\hline UT3 & TNS3 & TNS2 & NM2 & $\mathrm{NJ2}$ & NM1 & PA1 & SD1 & WA1 & ME3 \\
\hline VT1 & UT1 & WI A2 & NV3 & NV1 & TX1 & PA3 & SD3 & WI B1 & MN3 \\
\hline WV2 & WA2 & WI B3 & $\mathrm{SC} 1$ & OR3 & TX2 & UT2 & VA1 & WV1 & $\mathrm{NH} 2$ \\
\hline WY3 & WI B2 & WY1 & WY2 & WI A3 & VT3 & WA3 & WI A1 & WV3 & - \\
\hline
\end{tabular}


Table S6: Summary table of the $\mathbf{1 0}$ validation tests with the results of the four validation criteria.

\begin{tabular}{|c|c|c|c|c|}
\hline $\begin{array}{c}\text { Validation } \\
\text { Test no. }\end{array}$ & $\mathbf{q}^{\mathbf{2}}$ & $\mathbf{R}^{\mathbf{2}}$ & $\left.\mathbf{( R}^{\mathbf{2}}-\mathbf{R}_{\mathbf{0}}^{\mathbf{2}}\right) / \mathbf{R}^{\mathbf{2}}$ & $\mathbf{K}$ \\
\hline 1 & 0.65 & 0.68 & 0.04 & 1.0 \\
\hline 2 & 0.69 & 0.83 & 0.02 & 0.86 \\
\hline 3 & 0.68 & 0.68 & 0.0 & 1.03 \\
\hline 4 & 0.52 & 0.62 & 0.05 & 1.11 \\
\hline 5 & 0.58 & 0.67 & 0.01 & 0.90 \\
\hline 6 & 0.22 & 0.35 & 0.26 & 1.09 \\
\hline 7 & 0.57 & 0.68 & 0.01 & 1.01 \\
\hline 8 & 0.64 & 0.74 & 0.09 & 0.93 \\
\hline 9 & 0.54 & 0.65 & 0.09 & 1.09 \\
\hline 10 & 0.65 & 0.66 & 0.0 & 0.97 \\
\hline
\end{tabular}



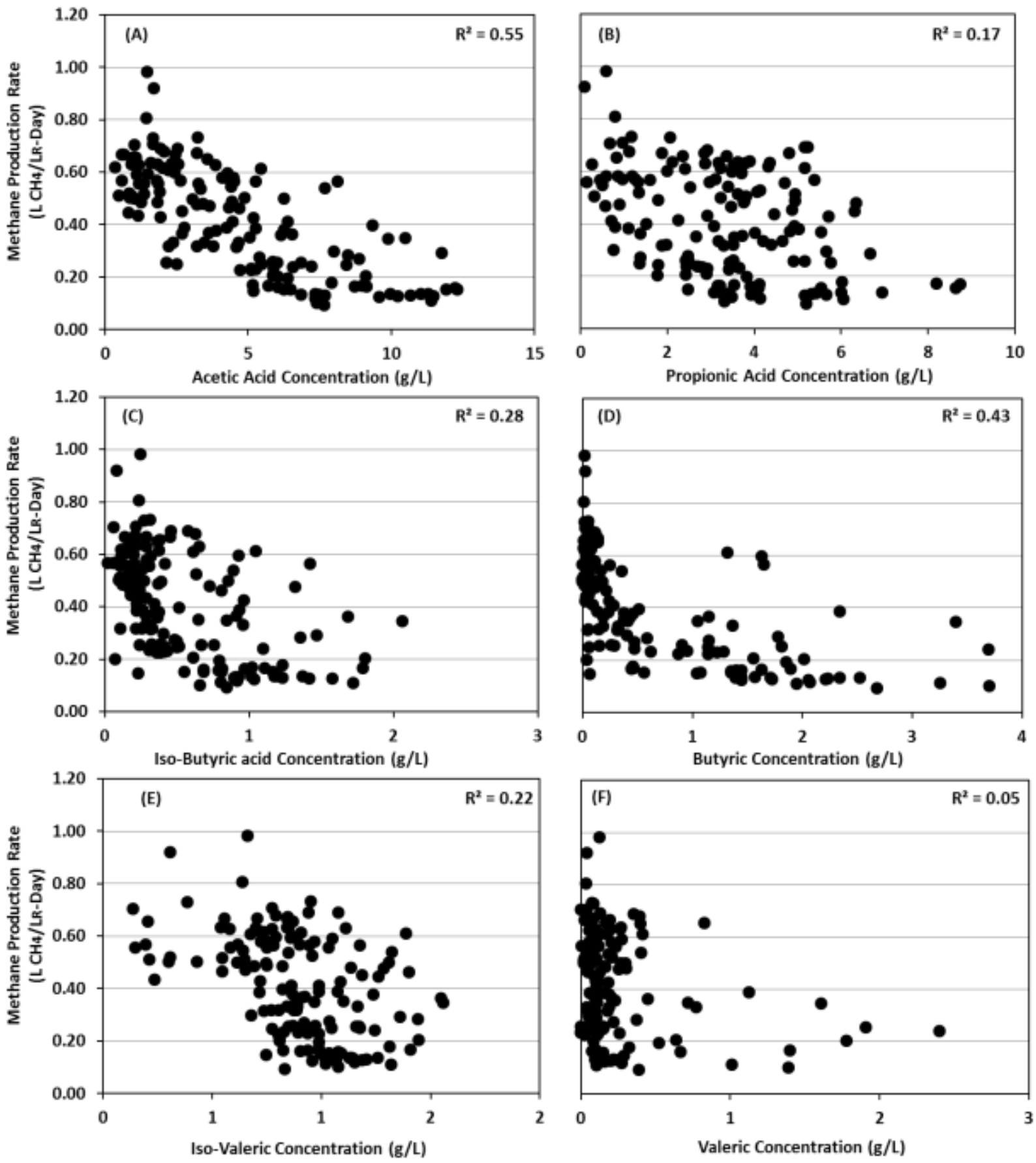

Figure S1: Average daily methane production versus individual VFA concentrations.

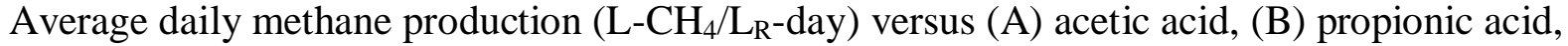
(C) iso-butyric acid, (D) butyric acid, (E) iso-valeric acid and (F) valeric acid concentration $(\mathrm{g} / \mathrm{L})$. Error bars are not included. 


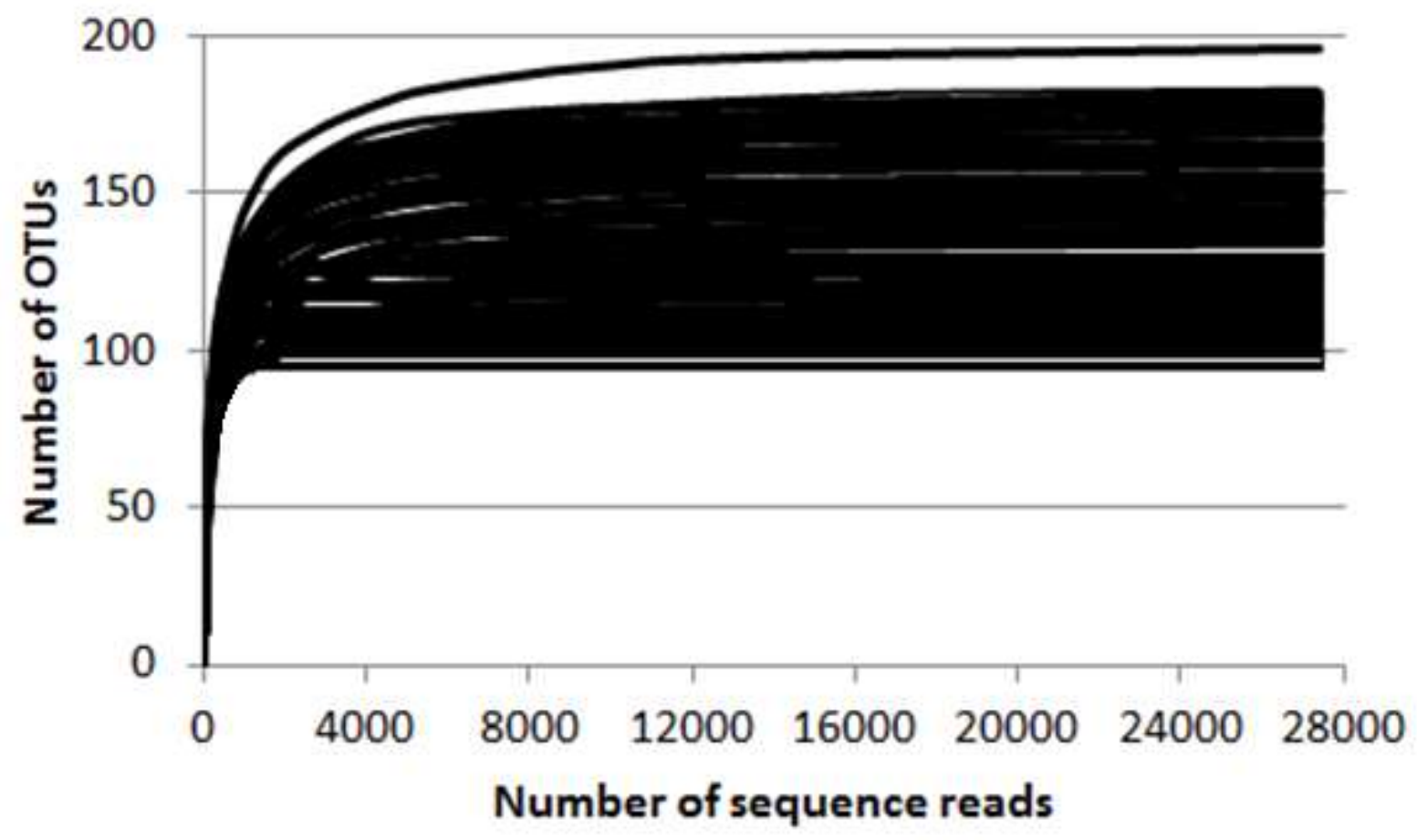

Figure S2: Rarefaction analysis for the assessment of OTU coverage.

Plot shows 149 rarefaction curves showing the increase in OTU numbers ( $\mathrm{Y}$ axis) as a function of the number of sequence reads (X axis). The number of sequence reads go up to 27, 315, which is the lowest observed among the 149 digester samples The curve becomes asymptotic as the OTU number saturates, and increasing the reads adds an increasingly smaller number of new OTUs, indicating adequate coverage for the samples tested. 


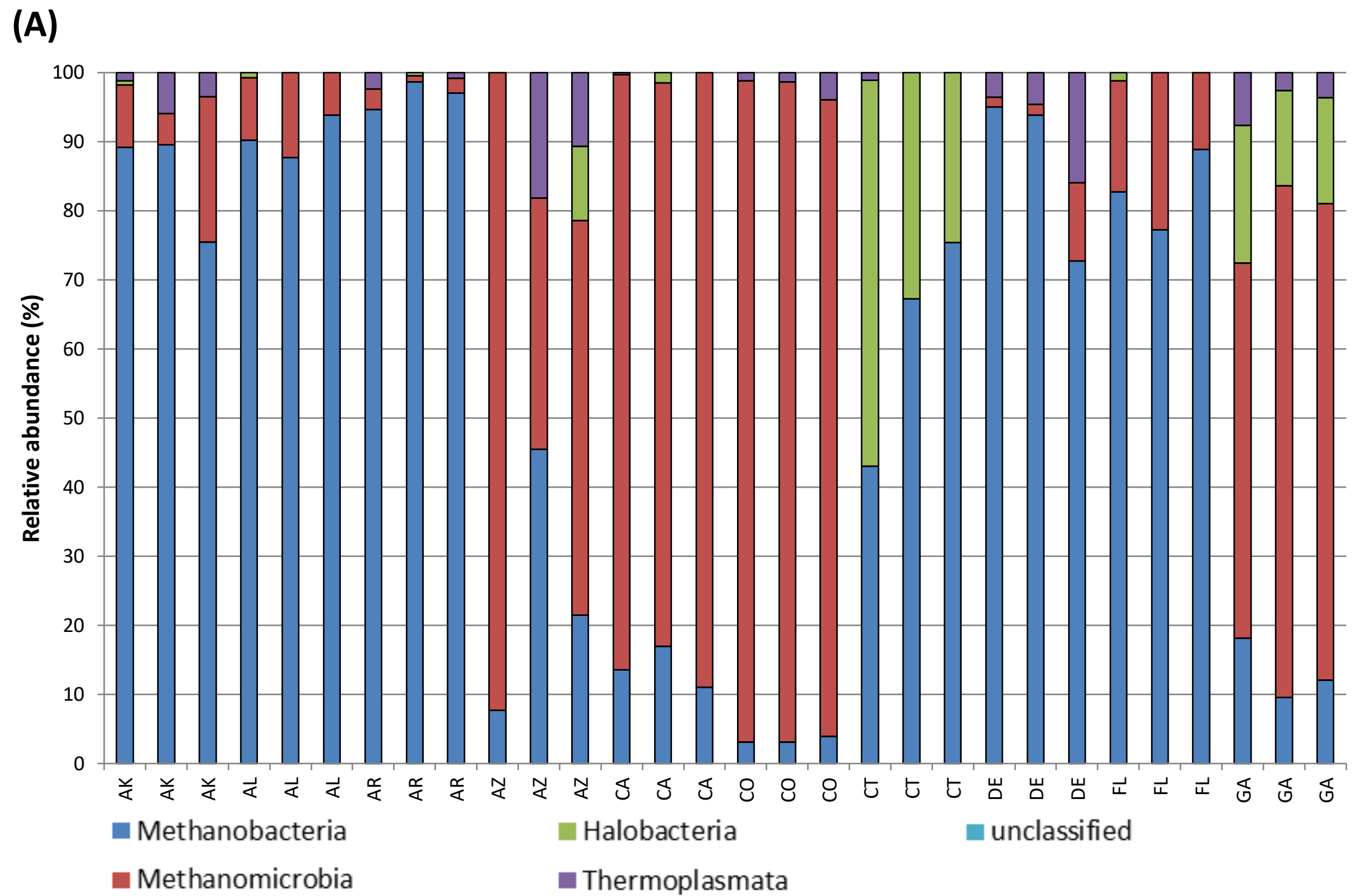


(B)

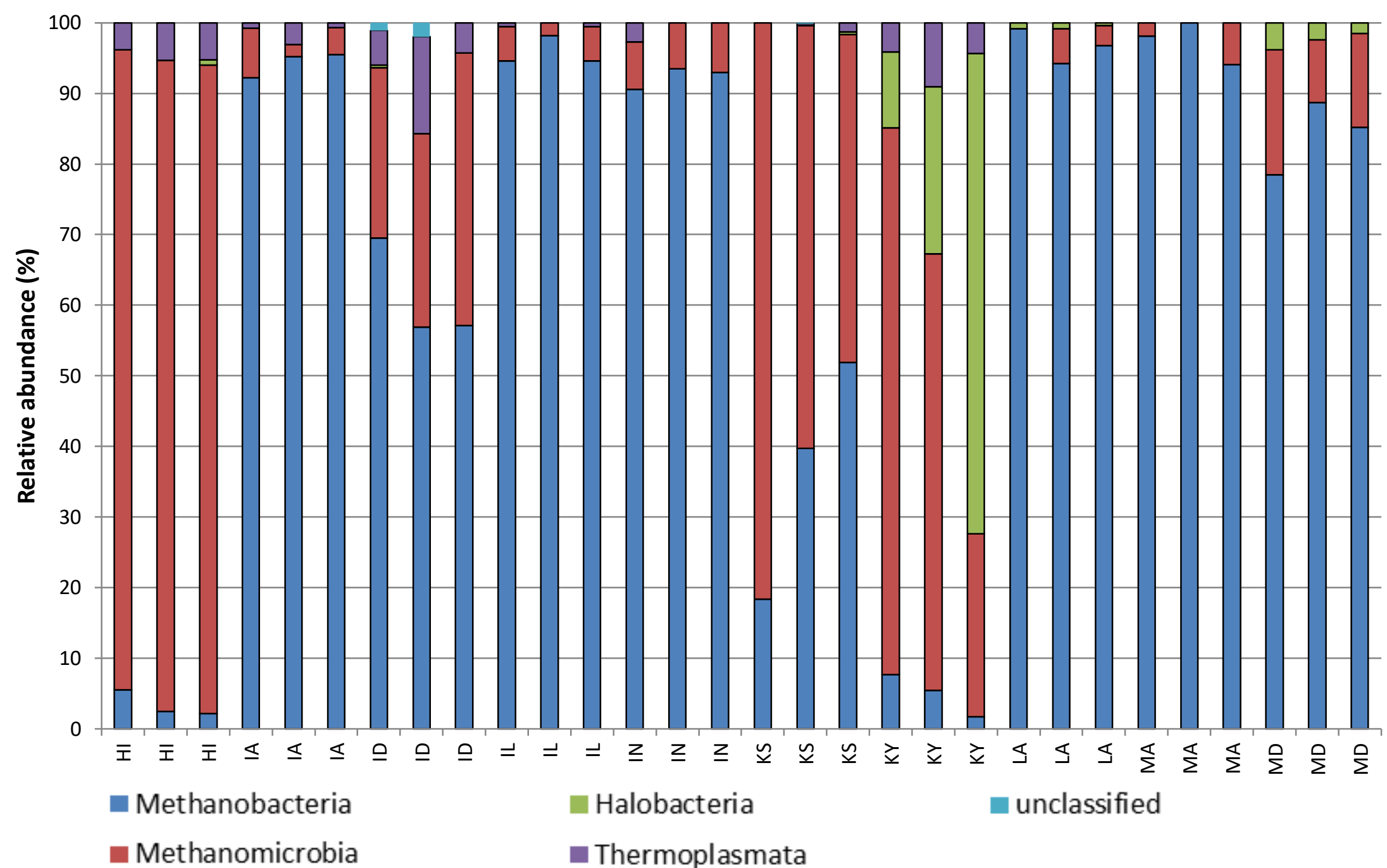


(C)

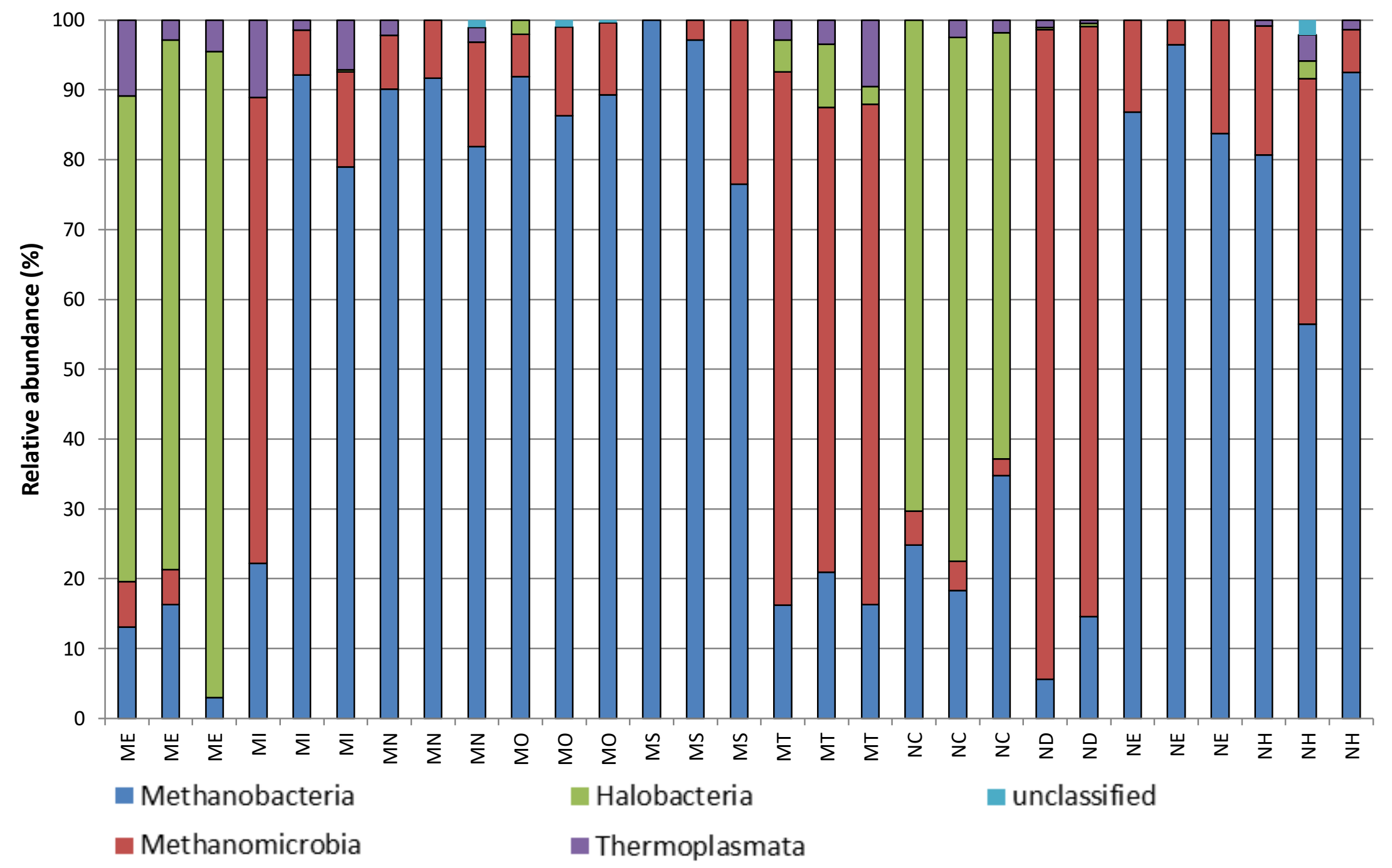


(D)

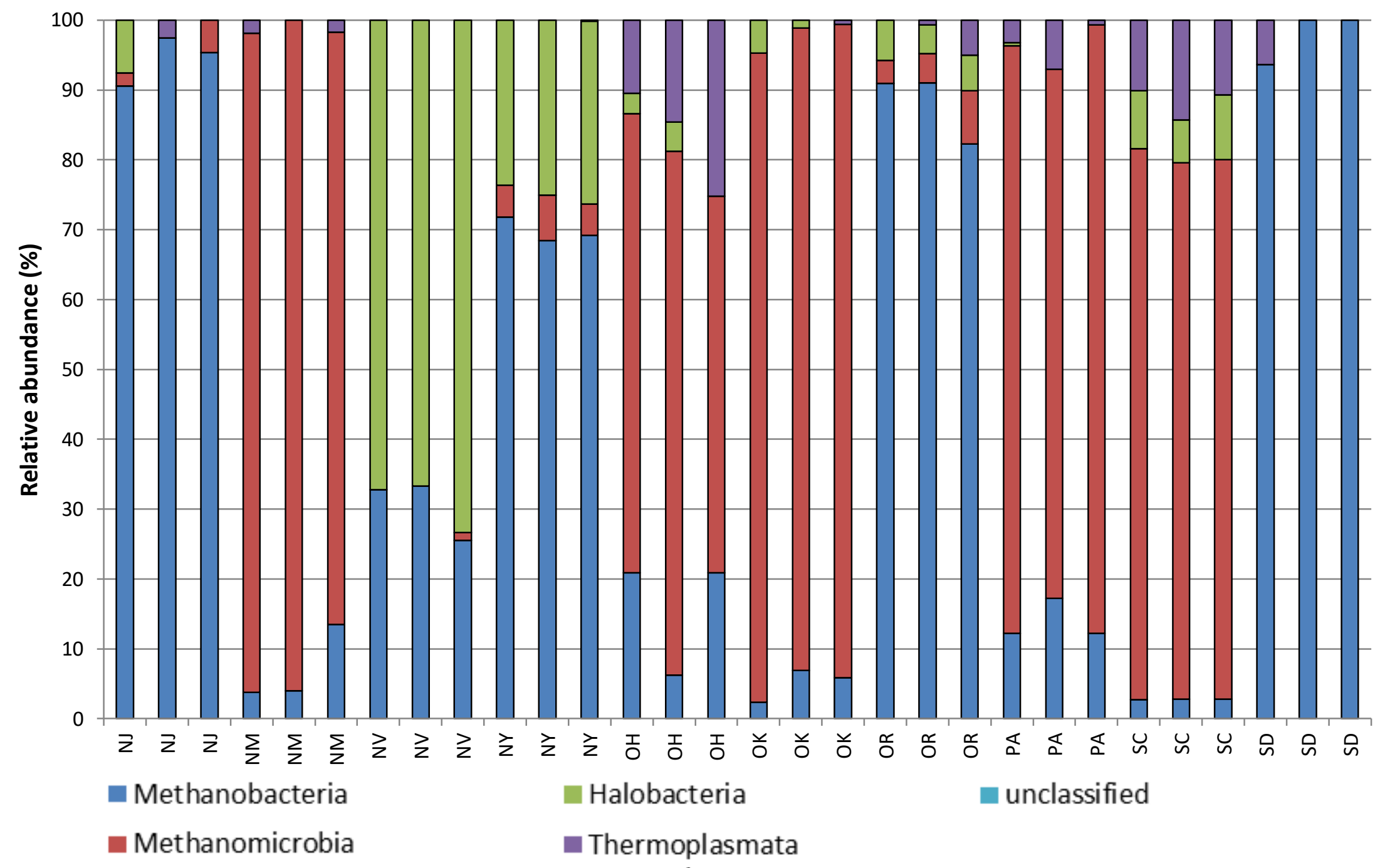


(E)

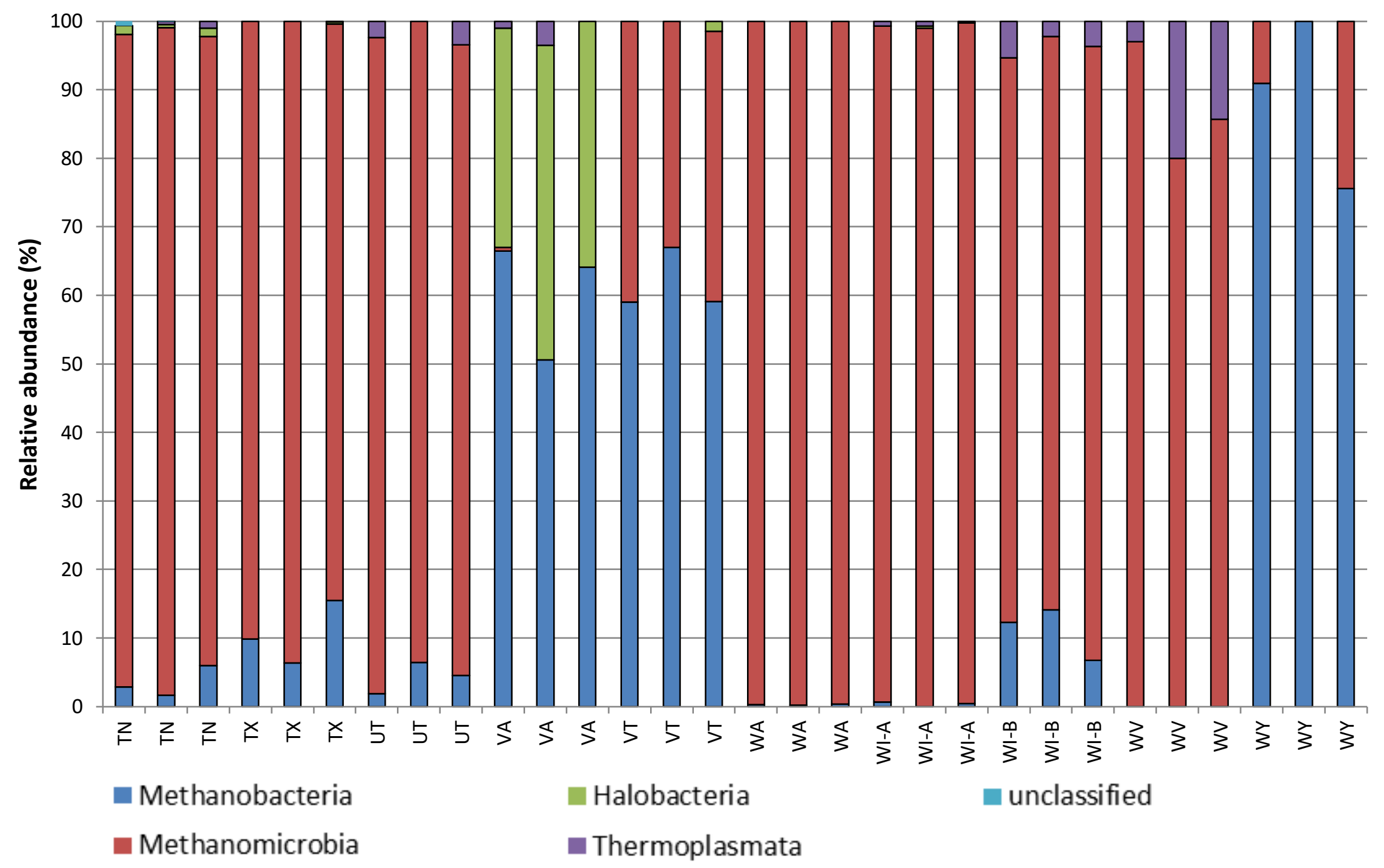


Figure S3: Archaeal community profile of 149 digesters at the class level. The profiles of 149 digesters are divided in to five stacked bar graphs A, B, C, D and E, respectively. The Y axis represents the relative abundance (\%) of Archaeal classes observed of the total Archaeal sequences in a digester sample. The digester sample on the X axis are labelled based on the US state(s) from where the seed source was obtained (i.e. AK = Alaska, HI = Hawaii etc.). Replicate digesters seeded from the same seed are given the same labels. 

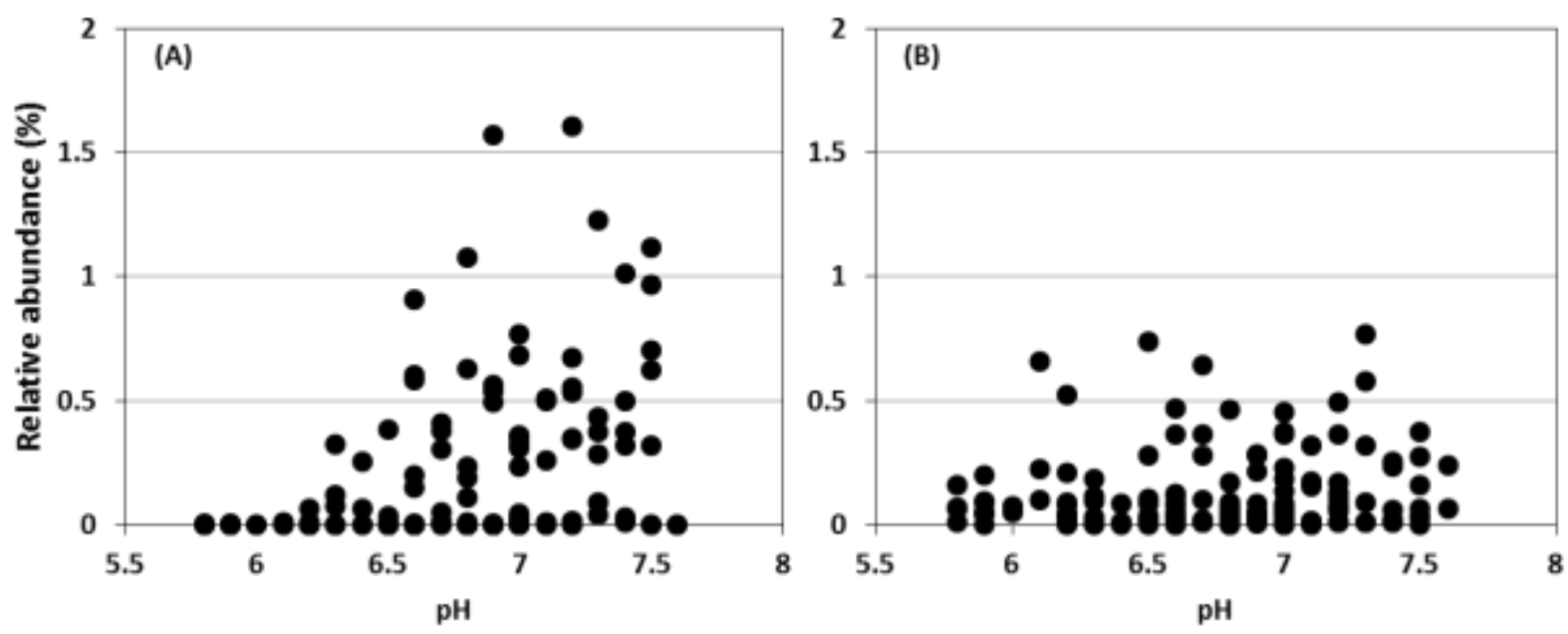

Figure S4: Percent relative abundance of dominant methanogens versus digester $\mathrm{pH}$. Percent relative abundance of (A) Methanosarcina and (B) Methanobacterium versus digester $\mathrm{pH}$. 
(A)

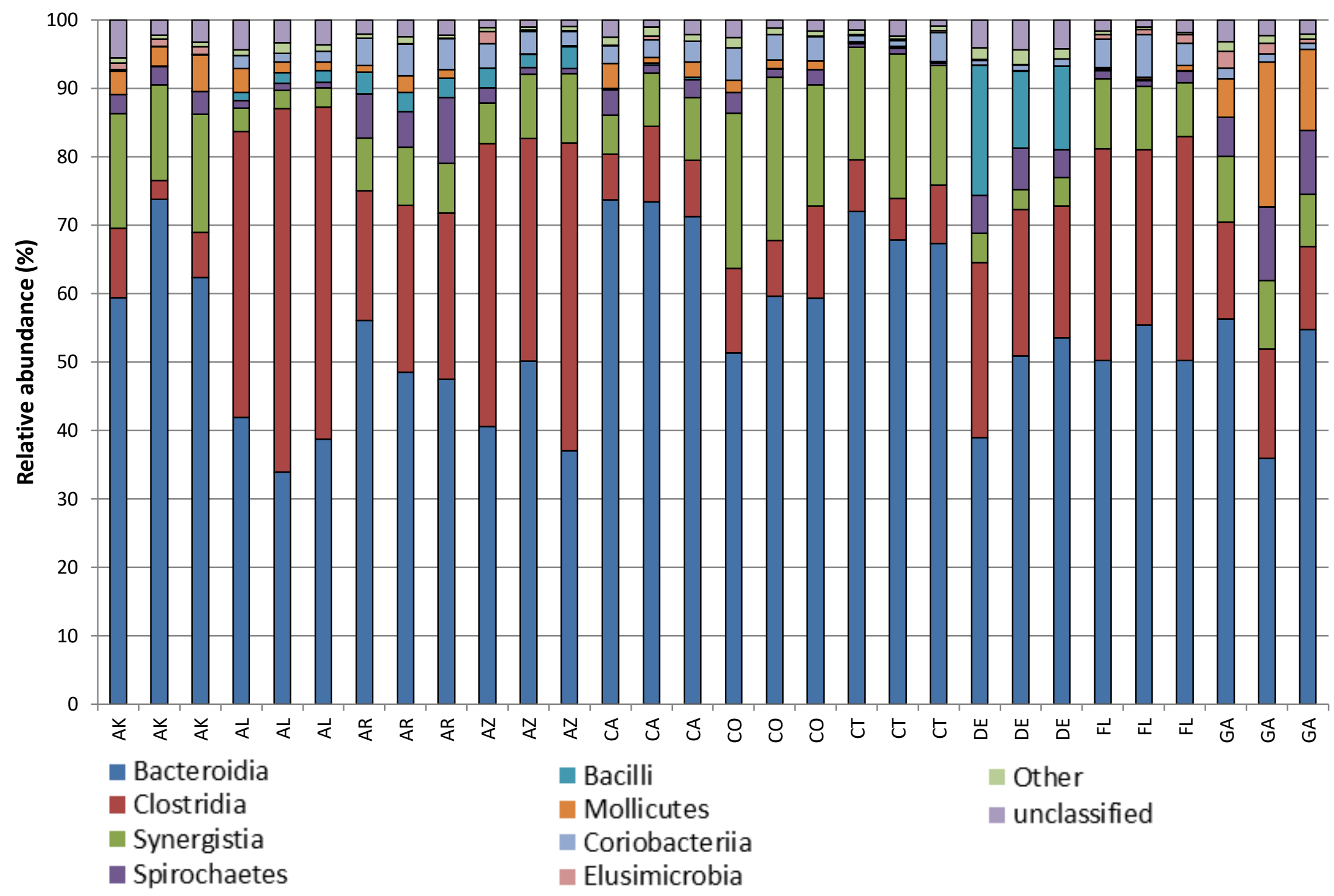


(B)

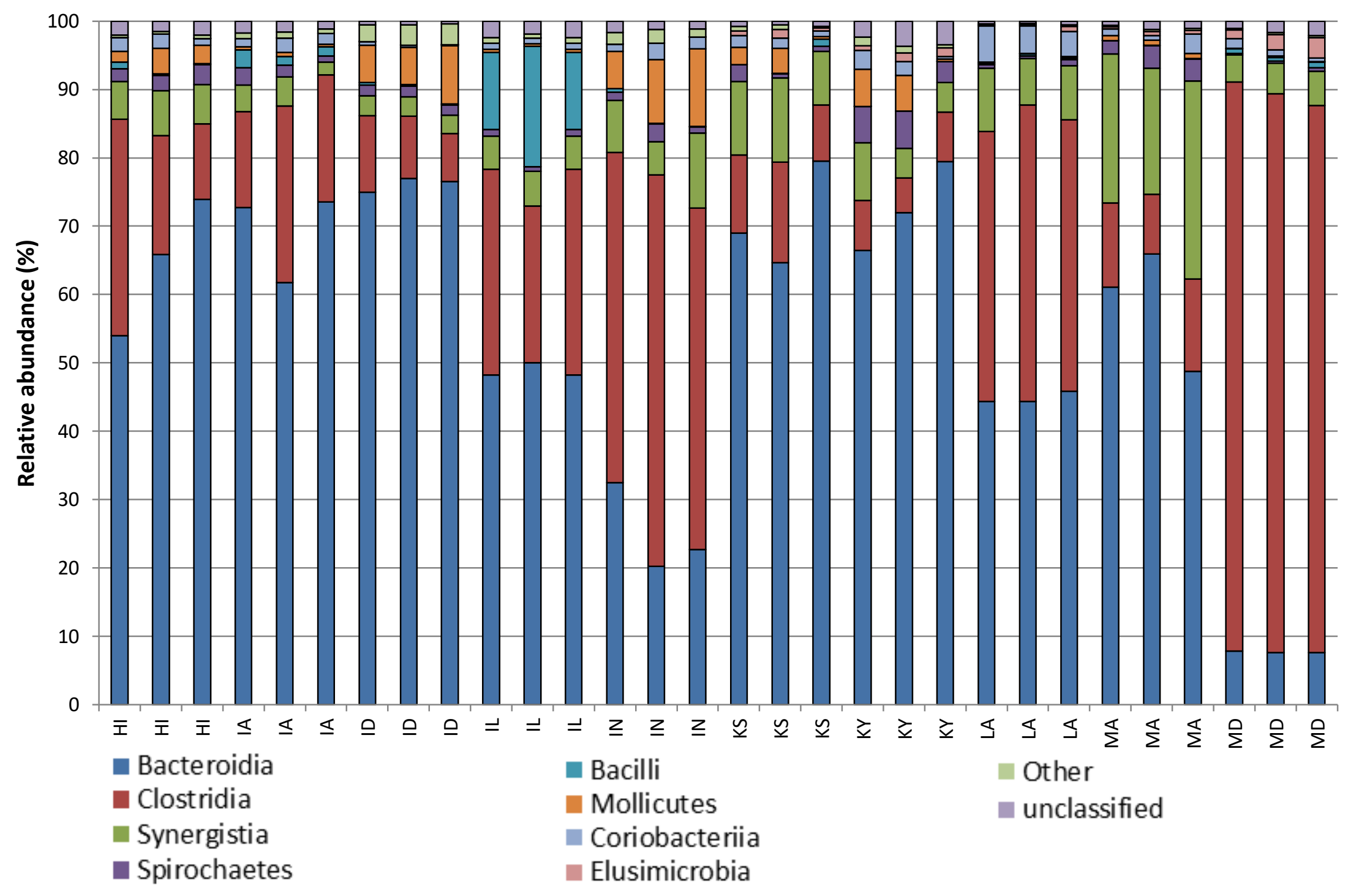




\section{(C)}

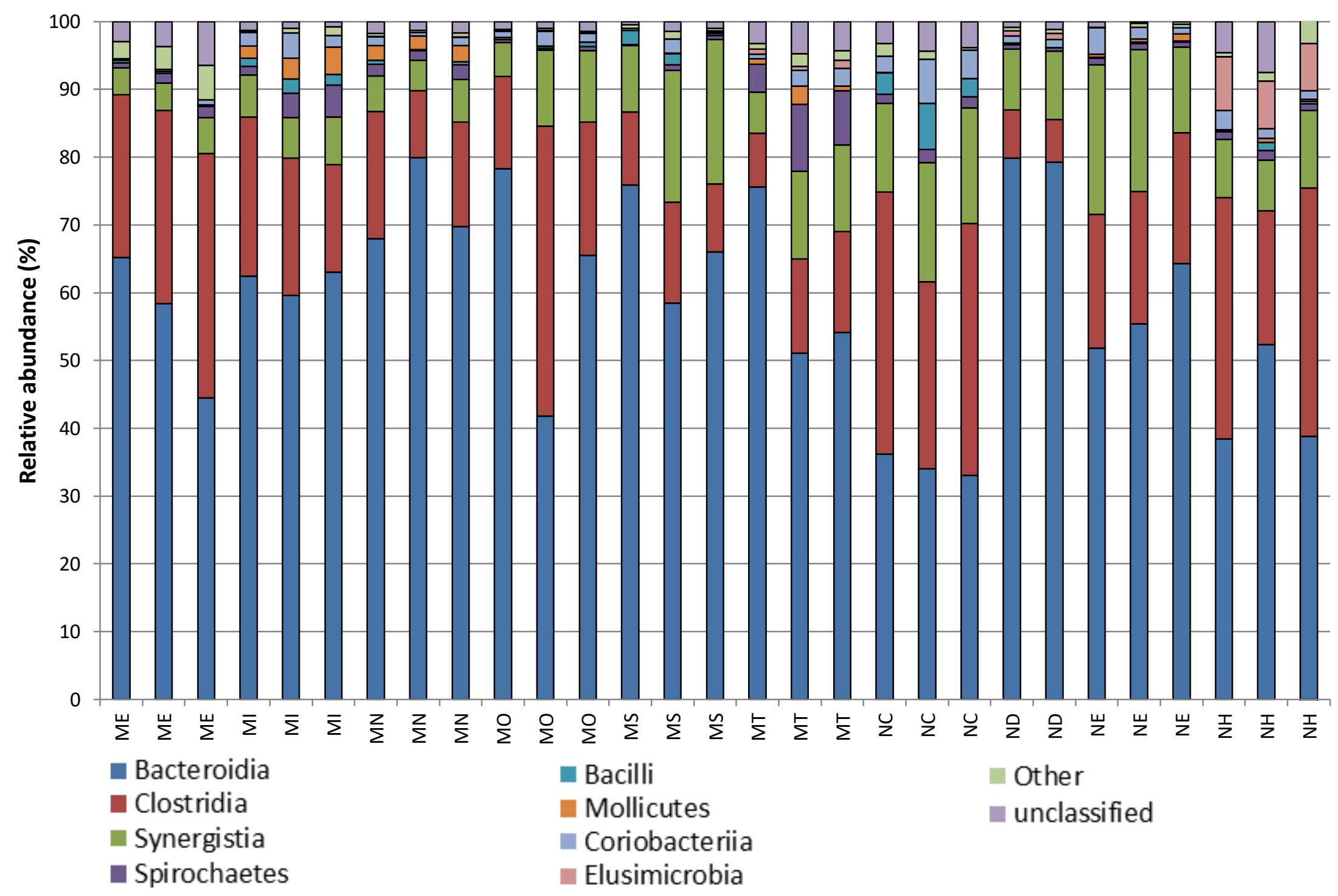




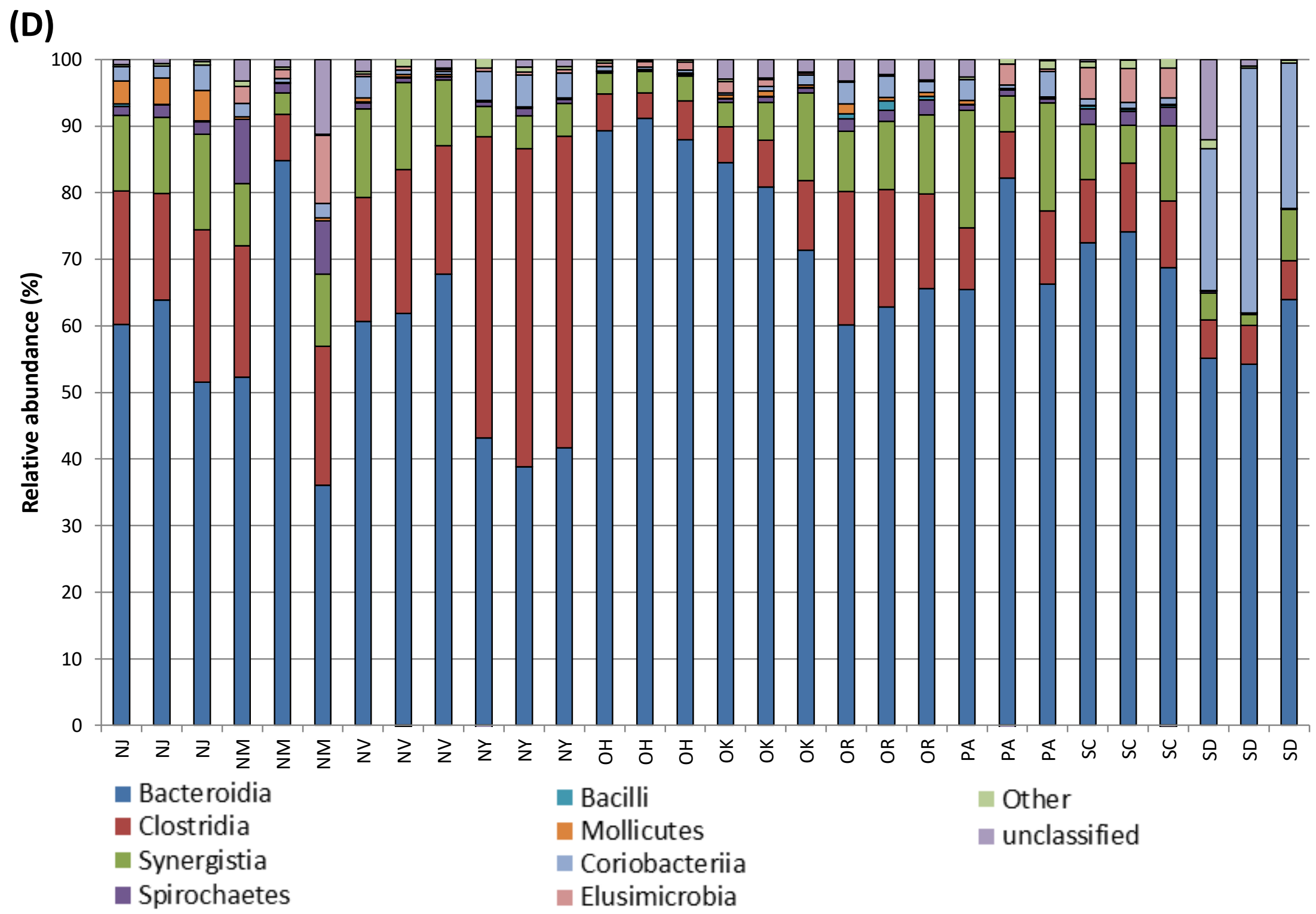


(E)

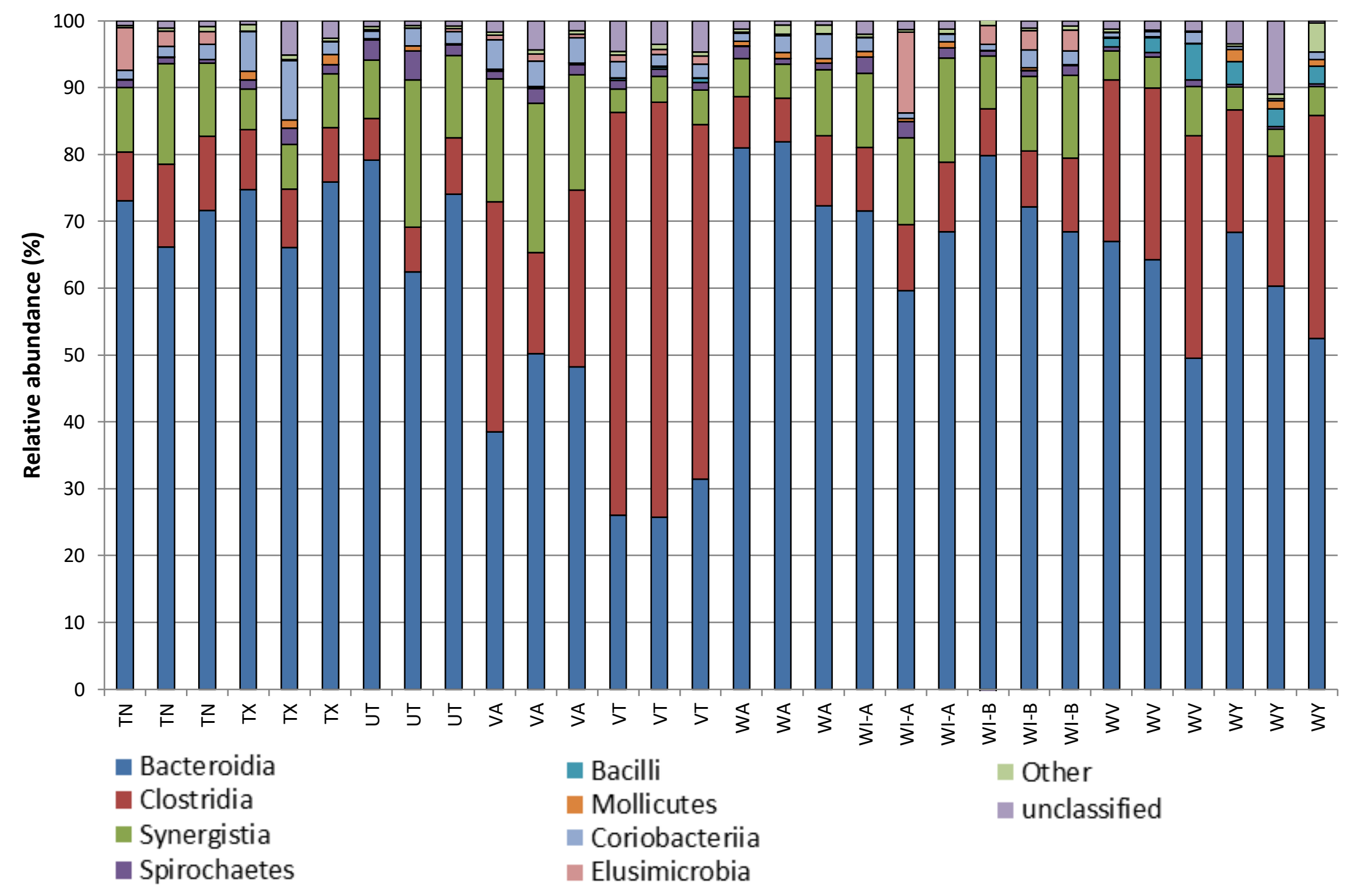


Figure S5: Bacterial community profile of 149 digesters at the class level. The profiles of 149 digesters are divided in to five stacked bar graphs A, B, C, D and E, respectively. The Y axis represents the relative abundance (\%) of Bacterial classes observed of the total Bacterial sequences in a digester sample. The digester sample on the $X$ axis are labelled based on the US state(s) from where the seed source was obtained (i.e. AK = Alaska, $\mathrm{HI}=$ Hawaii etc.). Replicate digesters seeded from the same seed are given the same labels. 
(A)
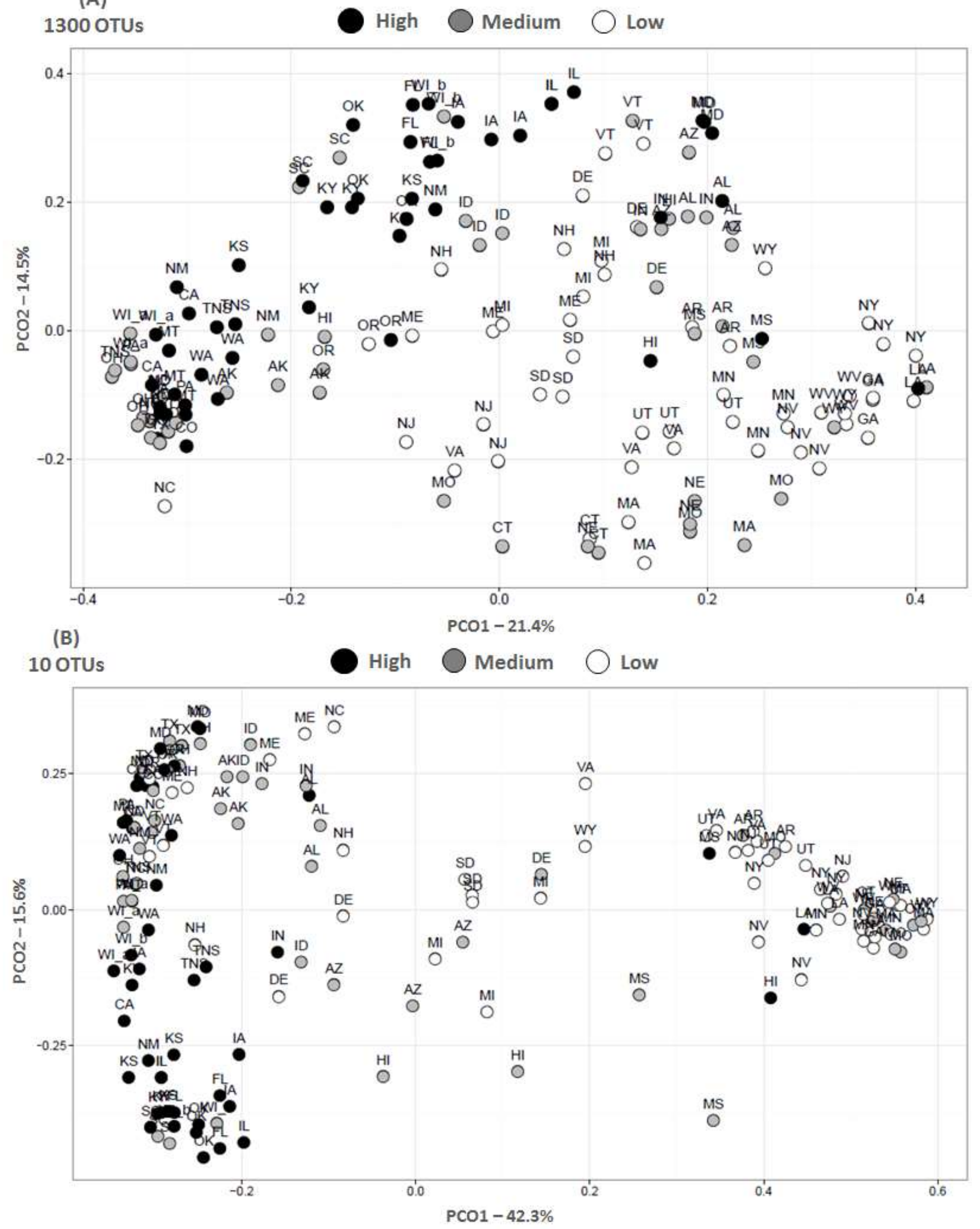
Figure S6: Microbial community principal component analysis (PCOA).

PCoA plots using (A) all 1300 OTUs and (B) 10 highly significant OTUs. Methane production rate classifications are shown as High (black), Medium (grey) and Low (white) symbols. 149 data points are show in both PCoA plots and labelled based on the US state(s) from where the seed source was obtained (i.e. $\mathrm{AK}=$ Alaska, $\mathrm{HI}=$ Hawaii etc.). Replicate digesters seeded from the same seed are given the same labels. 


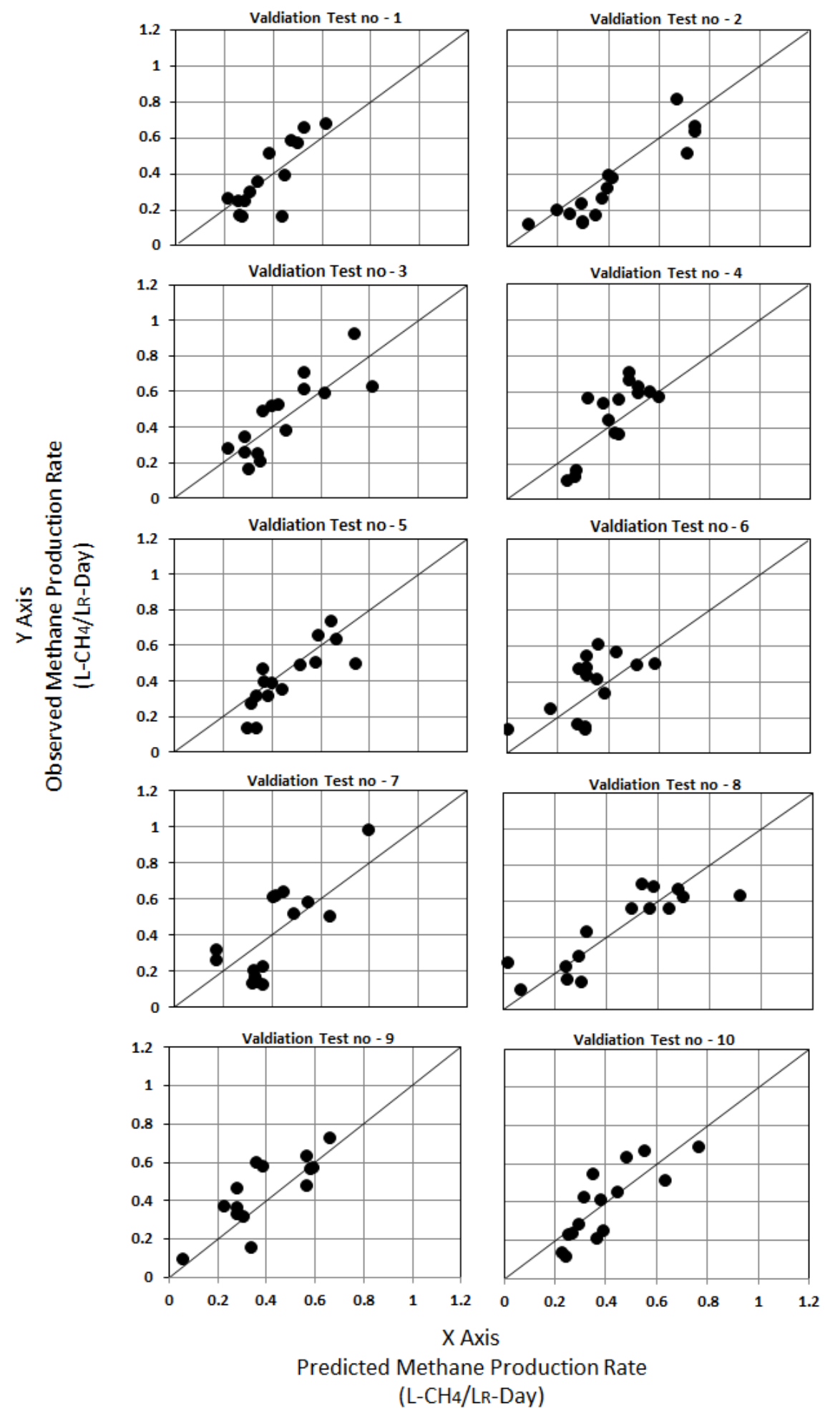

Figure S7: Summary plots of the 10 validation tests.

Results of validation tests using the highly significant OTUs. The data points are for digesters in the test set for each validation test. Values of the validation criteria $\left(q^{2}, R^{2}, R^{2}-R_{0}^{2} / R^{2}\right.$ and $\left.K\right)$ are shown in Table S6. The line in each plot represents the regression line with slope equal to one and intercept equal to zero. 